\title{
DEF: Una forma de ataque por sulfatos
}

\author{
$D E F:$ As a form of sulfate attack
}

J. SKALNY ${ }^{\star}$, V. JOHANSEN ${ }^{\star *}$, N. THAULOW $W^{* *}$ y A. PALOMO ${ }^{* \star *}$

(*) Consultant, Timonium, Maryland, U.S.A.

Fecha de recepción: 10-I-96

Fecha de aceptación: 7-III-96

\author{
(**) G.M. Idorn Consult (RAMBOLL UNA/S), Dinamarca
}

$(* * *)$ IETCC/CSIC, España

\section{RESUMEN}

DEF es el término habitualmente usado para describir la expansión que sufren algúnos hormigones de cemento portland que han sido curados con la ayuda de un tratamiento térmico. DEF es la abreviatura de la expresión inglesa "Delayed Ettringite Formation" que en español se podría traducir como "Formación de Etringita Retrasada". Aunque en los últimos tiempos se ha progresado significativamente, aún hoy dia no se entiende completamente el mecanismo exacto de la expansión en si misma. La formación de una etringita tardía es, en principio, consecuencia de la descomposición térmica de la etringita formada con anterioridad o durante el fraguado de la pasta de cemento, por un exceso de calor o inadecuado proceso de curado térmico. La observación, en el hormigón maduro, de etringita cristalina en poros, fisuras y en las interfases pasta-áridos no es en si una evidencia de la DEF, pero si es una consecuencia de la natural recristalización de la etringita en espacios disponibles. El fenómeno de la DEF depende de los materiales, del curado y de las condiciones ambientales, y puede fácilmente distinguirse por medio de la microscopía óptica y eletrónica de la reacción árido-álcali (ASR) y de otros mecanismos de deterioro.

\section{SUMMARY}

Delayed ettringite formation (DEF) is the term used to describe expansion of some heat cured portland cement concretes. Although meaningful progress has been made, the exact mechanism of the expansion itself is not entirely understood. The ettringite reformation is enabled, primarily, by thermal decomposition of ettringite formed prior to orduring the cement paste setting as a result of excessive/improper heat curing. Observance in mature concrete of crystalline ettringite in air voids, cracks, and gaps around the aggregate is not in itself an evidence for $D E F$, but is the consequence of natural recrystallization of ettringite into available larger spaces. Occurance of DEF is dependent on materials, curing, and environmental conditions, and can easily be distinguished from ASR and otherdeterioration mechanisms by optical and eletronoptical methods.

\section{INTRODUCCIÓN}

En el último lustro, se han publicado numerosas investigaciones en torno al tema de la Formación de Etringita Retrasada (DEF). Dicho tema ha llegado a convertirse en objeto de controversia, fundamentalmente a causa del incompleto

\section{INTRODUCTION}

In the past five years, numerous papers were dedicated to the subject of the so-called delayed ettringite formation or DEF. The DEF issue became controversial, primarily because of the incomplete knowledge on the mechanisms of delayed ettringite 
conocimiento existente sobre los mecanismos de formación de esta etringita retrasada y, en general, de los mecanismos de expansión relacionados con los ataques de los sulfatos, pero también debido a las diferencias en la nomenclatura usada por autores diferentes y, desde luego, al hecho de que este fenómeno puede ocurrir simultáneamente con otras formas de deterioro del hormigón,como por ejemplo la reacción árido-álcali (ASR).

Para una escuela de opinión, representada fundamentalmente por Carrasquillo, Hime y Marusin $(1,2)$, la DEF puede ser debida a: (i) incremento del contenido total de sulfatos en los cementos portland, (ii) incremento en el contenido de sulfatos en los clínkeres actuales, (iii) presencia en los clínkeres de sulfatos poco solubles (tal como el sulfato cálcico o anhidrita), (iv) uso de combustibles de bajo costo portadores de sulfatos- en la producción de clínker, (v) exceso de calor en el curado del hormigón y (vi) exposición del hormigón, una vez fraguado, a altas temperaturas ambientales. Según los citados autores, puede ser (desde el punto de vista experimental) muy difícil distinguir entre el deterioro producido por la DEF y el que genera la ASR.

En la opinión de los autores del presente trabajo, así como de otros autores (3-9), la DEF puede considerarse como un tipo de ataque interno de sulfatos ocasionado por un calor inadecuado durante el proceso de curado y/o en el almacenaje de elementos de hormigón. La DEF puede detectarse y distinguirse fácilmente de otras formas de deterioro del hormigón, tal como la ASR y el hielo-deshielo (10), a través, por ejemplo, de las microscopías óptica y electrónica. Además, nosotros, no creemos que la mayoría de los clínkeres de cemento portland contengan sulfato cálcico en forma de anhidrita; al contrario, en nuestra opinión la anhidrita se forma en los clínkeres muy raramente, si es que lo hace alguna vez. Finalmente, consideramos que el uso de combustibles que contienen azufre no influye en la calidad del clínker de manera que aumente su potencialidad para el desarrollo de la DEF en el hormigón.

Este trabajo es un estado del arte en torno al conocimiento actual sobre la DEF, lo cual no significa que deba considerarse como una fuente exhaustiva de referencias bibliográficas. Para obtener información adicional se ha de consultar la literatura citada.

\section{LA ETRINGITA EN EL HORMIGÓN: FORMAS Y EXPANSIÓN}

La etringita es un sulfo-aluminato cálcico hidratado cristalino, de fórmula $\mathrm{C}_{6} \mathrm{~A}_{\mathrm{S}_{3}} \mathrm{H}_{32}$. Es un producto que se formation and sulfate-related expansions in general, but also due to the differences in nomenclature used by different authors and the fact that it can occur simultaneously with other forms of deterioration, such as alkali-silica reaction (ASR).

Per one school of thougth, represented by Carrasquillo, Hime, and Marusin (e.g., 1,2), DEF can be caused by: (i) increased total sulfate content in typical portland cements, (ii) increased sulfate content in present-day clinkers, (iii) presence in clinkers of slowly-soluble sulfate compounds (such as calcium sulfate anhydrite); (iv) use of low-cost sulfate-bearing fuels in clinker production, (v) excessive heat-curing of the concrete; and (vi) exposure of set concrete to high ambient temperature. According to the above authors, it may be experimentally difficult to distinguish between DEF and ASR damage in concrete.

In view of the present authors and others (e.g., 3-9). $D E F$ may be viewed as a form of internal sulfate attack caused by improper heat curing and/or storage of portland cement concrete. DEF can be easily detected and distinguished from other forms of concrete deterioration such as ASR and frost damage (10), for example, by optical and electron-optical methods. Also, we do not believe that the majority of the portland clinkers contain calcium sulfate anhydrite; to the contrary, it is our opinion that anhydrite forms in clinkers very seldom, if ever. It is also our belief that use of sulfur-containing waste fuels does not influence clinker quality in a manner that would increase its potential for DEF in concrete.

This paper represents a state-of-the-art review of the current knowledge on $\mathrm{DEF}$, but is not ment to be a complete source of literature references. For additional information, please check references in the quoted literature.

\section{ETTRINGITE IN CONCRETE: FORMS AND EXPANSION}

Ettringite, a crystalline calcium sulfate aluminate hydrate, for simplicity $C . A \bar{S}_{3} H_{32}$, is a normal product 
forma en la normal hidratación del cemento portland y su presencia en la pasta endurecida, en sí misma, no representa un problema para la durabilidad del hormigón. En una pasta de cemento normal, la etringita se forma como consecuencia de las reacciones entre los aluminatos y ferritos cálcicos anhidros presentes en el clínker y los sulfatos que, generalmente en forma de yeso, se mezclan con dicho clínker para producir el cemento. Bajo condiciones normales de curado y uso, tal etringita no produce expansión. La cantidad de etringita formada en la pasta a un tiempo dado es difícil de predecir porque depende de múltiples, y no siempre conocidas, condiciones. La composición química del cemento y el tamaño de partícula, la reactividad (solubilidad, velocidades de hidratación y cristalización) y la abundancia relativa de los componentes individuales del clínker, la composición de la fase líquida en el interior de los poros, la presencia de $\mathrm{CO}_{2}$, y las condiciones de curado, incluyendo la temperatura y la humedad relativa, son sólo unas pocas de las muchas condiciones posibles.

La etringita forma parte de cualquier pasta de cemento portland y se puede detectar con facilidad, en un hormigón maduro expuesto a una gran variedad de condiciones ambientales, fundamentalmente en fisuras y huecos. La etringita se forma en el hormigón como consecuencia de las reacciones químicas entre los componentes del cemento portland, pero también crece y se "redeposita" en espacios disponibles, debido a un proceso de envejecimiento conocido en química-física con el nombre de "Ostwald ripening". En términos simples, el principio del "Ostwald ripening" se basa en lo siguiente: los cristales pequeños tienen una tendencia a crecer debido a una necesidad natural de disminución de su energía de superficie. Tal recristalización se ve favorecida por un contenido alto de humedad, que permite un proceso continuo de disolución, transporte y recristalización en los espacios vacíos disponibles. La cristalización de este tipo de etringita en el hormigón endurecido no genera expansión.

\section{Formas de Etringita}

En la presente discusión en torno al fenómeno de la DEF, se considerarán tres formas diferentes de etringita, atendiendo a los posibles mecanismos de formación:

Etringita Primaria: Es un producto normal de la reacción de hidratación del cemento portland. A nivel macroscópico, se distribuye homogéneamente en la matriz de cemento del hormigón endurecido. Su formación inicial en el hormigón de cemento portland no genera expansión. La etringita primaria se forma también en hormigones de cemento resistente a los sulfatos, así como también en hormigones fabricados of portland cement hydration and its presence in the hardened paste does not, in itself, represent a concrete durability problem. In normal cement paste, ettringite forms as a result of reactions between anhydrous calcium aluminates and ferrites of the clinker and the sulfates present in the added gypsum and in the cement clinker. Under normal conditions of curing and use, such ettringite does not lead to expansion. The amount of ettringite formed in the paste at a certain time is difficult to predict because it depends on multiple, not completely understood conditions. Cement chemistry and particle size, reactivity (e.g.,solubility, rate of hydration and crystallization) and relative abundance of individual clinker components, pore solution composition, presence of $\mathrm{CO}_{2}$, and curing conditions, including temperature and relative humidity, are only few of the many possible conditions.

Ettringite forms as part of any portland cement paste and can easily be detected in durable concrete exposed to a variety of environmental conditions, primarily in cracks and voids. Ettringite forms in concrete as a consequence of chemical reactions between portland cement components, but is also growing and is redeposited in available spaces as a consequence of an ageing process known in physical chemistry as "Ostwald ripening". In simple terms, the principle of such ripening is as follows: Small crystals have the tendency to grow due to the natural need to decrease their surface energy. Such recrystallization is benefited by high moisture content enabling continuous process of dissolution, transport, and recrystallization into the available empty spaces. Crystallization of such ettringite in hardened concrete is non-expansive.

\section{Forms of Ettringite}

For the purpose of this DEF discussion, we will consider three mechanistically different modes of ettringite formation:

Primary ettringite: Primary ettringite is a normal product of early portland cement hydration and, at macroscopic level (optical microscopy), is homogeneously distributed in the paste matrix of the hardened concrete. Its initial formation in portland cement concrete does not lead to expansion. Primary ettringite is also formed in sulfate resistant as well as blast furnace slag cement concretes without causing 
con cementos siderúrgicos sin ocasionar expansiones. Estos hormigones, generalmente, no expanden, incluso cuando se someten al contacto con fuentes externas de sulfatos.

La etringita que se forma como consecuencia del ataque externo de sulfatos (quizás la más dañina desde el punto de vista de sus efectos expansivos por producirse en hormigones endurecidos, ya puestos en servicio) puede considerarse como etringita primaria si se atiende al tipo de mecanismo que la genera.

Etringita Secundaria: En el hormigón endurecido y húmedo $y$, tras un tiempo suficiente, la etringita presente experimentará una eventual disolución y subsiguiente recristalización en los espacios disponibles más grandes. Este fenómeno sucede independientemente de si la etringita se formó originalmente como "primaria" o como "retrasada" (ver más adelante). Este tipo de etringita se denomina secundaria y su formación, tal y como es definida aquí, no genera expansión.

Etringita Retrasada: Es un hecho bien conocido que la etringita primaria es inestable por encima de aproximadamente $65-70^{\circ} \mathrm{C}$. Así, bajo semejantes condiciones de curado, la etringita primaria no se formará y la que se pudiera haber formado con anterioridad al curado, se descompondrá. Si el hormigón así curado se mantiene posteriormente en agua o en condiciones húmedas a temperatura ambiente, la etringita se formará lentamente en la matriz de pasta de cemento. Este proceso ha sido denominado "formación de etringita retrasada" (DEF) y se ha observado que genera expansión con las consecuentes fisuraciones en pastas, morteros $u$ hormigones. La expansión asociada con la formación de dicha etringita no es, hoy día, completamente comprendida, siendo varios los mecanismos posibles que están siendo explorados.

En algunas referencias bibliográficas, los términos "etringita retrasada" y "etringita secundaria" se usan indistintamente, creando así una cierta confusión con respecto al carácter expansivo de la etringita. Por esto nosotros preferimos evitar el uso general del término $\mathrm{DEF}$, y hacer, en cada caso, referencia a las condiciones individuales de formación de la etringita.

\section{Razones que justifican la expansión interna asociada al ataque de los sulfatos.}

¿Bajo qué condiciones puede la etringita formada en hormigones, ya endurecidos, generar expansión? Ésta es una pregunta difícil de contestar, dado que la their expansion; such concretes do usually not expand even when subjected to external sources of sulfate.

Ettringite formed through the external sulphate attack (probably the most harmful if expansive effects are taken in account since it is produced in hardened concrete) can be considered as primary ettringite because of the mechanism by which it is formed.

Secondary ettringite: In hardened moist concrete, and given enough time, the ettringite present will eventually undergo dissolution and subsequent recrystallization into the largest available spaces; this happens whether the ettringite was originally formed as "primary" or as "delayed" (see below). This type of ettringite is referred to as secondary ettringite. Its formation, as defined here, does not lead to expansion.

Delayed ettringite: Primary ettringite is known to be unstable above approx. $65-70^{\circ} \mathrm{C}$. Thus, under such curing conditions primary ettringite will not form and that formed prior to the curing will decompose. If such concrete is subsequently kept in water or humid conditions at ambient temperature, ettringite slowly forms and reforms in the cement paste matrix. This process has been named "delayed ettringite formation" (DEF) and is observed, after cooling, to be followed by expansion and possible cracking of the paste, mortar or concrete. The expansion associated with formation of such ettringite is not completely understood and several possible mechanisms are being explored.

In some of the open literature, the terms "delayed" and "secondary" ettringite are used interchangeably, thus creating confusion with respect to ettringite expansivity. For this reason we prefer to avoid the general use of the term $D E F$, and rather refer in each case to the individual conditions for the formation of ettringite.

\section{Reasons for Internal Sulfate-Related Expansion}

Under what conditions can ettringite forming in already hardened concrete lead to expansion? This is a difficult question to answer as the expansive 
conducta expansiva es un proceso complejo que no puede predecirse fácilmente $(3,6)$. Sin embargo, un extenso bagage de conocimientos y experiencias está ya a nuestra disposición.

La acción de cantidades excesivas de sulfatos, de procedencia externa $o$ interna, se denomina genéricamente como "ataque por sulfatos" (11). Este nombre cubre varios procesos posibles o sus combinaciones, que producen expansión o fisuraciones o descomposición de los principales productos de hidratación del cemento. La DEF, el tema de discusión del presente trabajo, representa una de las formas de deterioro del hormigón relacionadas con la formación de etringita. Consiste en un ataque "interno" de sulfatos, caracterizado por la descomposición, o no formación, y la subsiguiente recristalización de etringita, debido a un inadecuado curado térmico. En la Figura 1 se muestra un resumen de los tipos de problemas relacionados con el ataque interno de los sulfatos (4). behaviour is a complex process that cannot be easily predicted $(3,6)$. However, a vast body of knowledge and experience is already available.

The action of excessive amounts of external or internal sulfate is referred to as "sulfate attack" (11). This name covers several possible processes or their combinations, leading to expansion or cracking or decomposition of principal products of cement hydration. DEF, the topic of this discussion, is only one of several forms of ettringite-related concrete deterioration. It represents an "internal" sulfate attack characterized by decomposition or non-formation, and subsequent reformation or formation of ettringite due to improper heat curing. An outline of possible types of internal sulfate-related problems is given in Figure I (4).

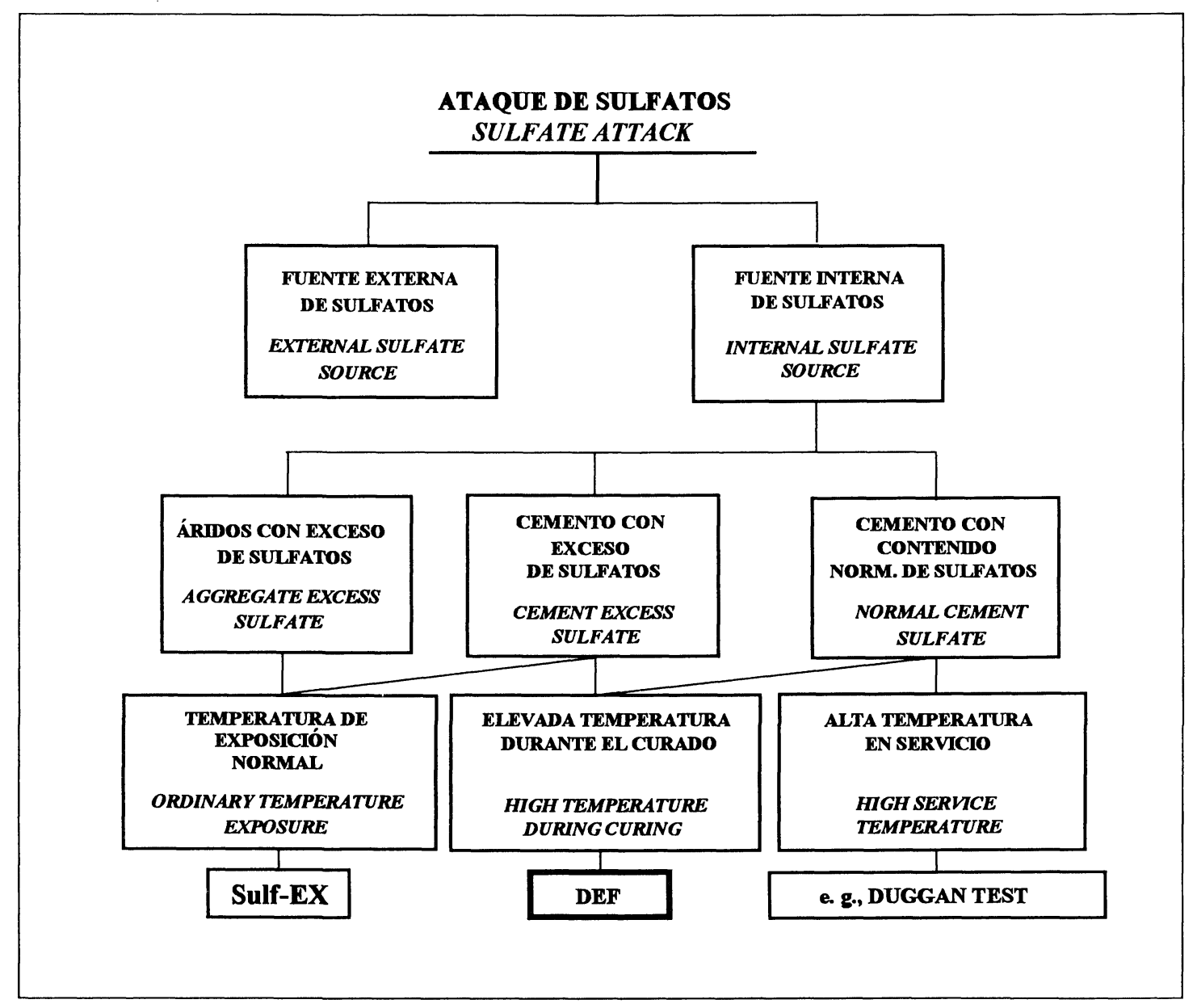

Fig. 1.- Esquema de posibles ataques internos de sulfatos en el hormigón. DEF es uno de los mecanismos posibles que generan daños.

Fig. 1.- Schematics of possible internal sulfate attack variations in concrete. DEF is only one of the possible mechanisms of sulfate-related internal damage. 
De acuerdo con algunos autores, la expansión, debida al ataque interno de los sulfatos, puede ocurrir sólo si hay una fuente de sulfatos $y / 0$ fases aluminicas y ferríticas procedentes de los componentes anhidros del cemento, tal como el $\mathrm{C}_{3} \mathrm{~A}$ o el $\mathrm{C}_{4} \mathrm{AF}$, que permitan supersaturaciones locales con respecto a la etringita. Expansiones debidas a la formación de etringita pueden ocurrir, además, cuando cantidades excesivas de yeso u otros sulfatos solubles, también en cantidades por encima de los niveles normales, están presentes en el cemento. Por esta razón, la mayoría de las normas limitan los contenicios de sulfatos en los cementos. Una tercera forma de reacción que involucra a los sulfatos es la formación de etringita observada después de un curado térmico y el enfriamiento subsiguiente... el tipo que nosotros llamamos "formación de etringita retrasada". Un elevado número de trabajos $(3,5,7,12-17)$, ha demostrado que las pastas, morteros y hormigones expuestos, durante el proceso de fraguado y de endurecimiento, a temperaturas demasiado altas, sufren expansión y posiblemente fisuración tras su exposición a la humedad en el curado y almacenamiento

Los posibles mecanismos por los que discurren los ataques de los sulfatos han sicio descritos por diversos autores $(5,6,11,18)$. Dado que el tema es complejo, en este punto nosotros nos limitaremos a dar luz en torno a los hechos mas relevantes:

- En la mayoria de las reacciones de hidratación, incluyencio la de la formación de etringita, el volumen de las fases sólidas aumenta, lo que en principio podría anunciar una posibilidad de expansión. Sin embargo, para un sistema abierto no hay una relación simple entre el cambio de volumen de las fases sólidas durante la hidratación de un cemento y el cambio en el volumen del material en su conjunto; consecuentemente, la formación de etringita puede ser, o no, origen de expansiones. Todo ello está relacionado al hecho de que durante los cambios de volumen, la microestructura, el sistema poroso, etc, juegan un papel importante.

- No existe una correlación sencilla entre la cantidad de etringita formada en un sistema y el grado de expansión de dicho sistema. De esta manera es imposible predecir la expansión que puede sufrir un hormigón exclusivamente sobre la base de la formación de etringita. Los cementos sulfo - resistentes y algunos cementos expansivos son claros ejemplos de este hecho.

La expansión dependerá del valor relativo de las fuerzas expansivas y de las que mantienen la estructura compacta. Un hormigón débil será más susceptible de sufrir daño que un hormigón de aíta calidad. Un hormigón previamente alterado por cualquier forma de deterioro será más sensible a una segunda forma de daño
According to one view, expansion due to internal sulfate attack may occur only if there is a source of sulfate and/or aluminate and ferrite from anhydrous cement components, such as $C_{f} A$ or $C_{A} A F$, thus enabling local supersaturation with respect to ettringite. Deleterious expansion due to formation of eitringite may also occur when excessive amount of gypsum or other soluble sulfates, in amounts well above normal levels, are present in the cement. For this reason, most standards limit the amount of sulfate in cements. Third form of reaction involving sulfates is the formation of ettringite observed after heat curing and subsequent cooling ... the type we call "delayed ettringite formation". A large number of experiments $(3,5,7,12-17)$ has shown that pastes, mortars and concrete exposed during the setting/hardening process to too high temperatures show expansion and, possibly, cracking after exposure to moist curing and storage.

The possible sulfate attack mechanisms were well characterized by several authors(e.g., 5,6,11,18). Because the issue is complex, at this place we will only highight some of the most relevant facts:

- During most hydration reactions, including that of formation of ettringite, the volume of solid phases increases, thus there is a possibility for expansion. However, for an open system there is no simple relationship between the change in the solid volume curing hydration of a cementitious material and the change in the volume of the material as a whole, thus ettringite formation may or may not cause expansion. This is related to the fact that during the volume change the porosity, microstructure, and pore structure, among other factors, play an important role.

-There is no simple relationship between the amount of ettringite formed in a system and the degree of expansion of the system. Thus, it is impossible to predict concrete expansion on the basis of ettringite formation alone. Sulfate-resisting and various expansive cements are good examples.

The expansion will depend on the relative value of the expansive forces and those holding the structure together. A weak concrete will be more prone to be damaged than a high-quality concrete. Concrete previously damaged by any form of deterioration will be more sensitive to a second form of damage than a 
que un hormigón normal. Las fuerzas expansivas deteriorarán la matriz del hormigón con mas intensidad en las primeras etapas de desarrollo de propiedades que en los últimos estadios. Así, la formación de etringita en el hormigón endurecido puede, o no, ser causa de expansión.

-Cantidades considerables de etringita pueden formarse dentro de el hormigón sin ocasionar expansiónes ni fisuraciones. La cantidad de tal etringita (no dañina) depende, entre otros factores, de la relación agua/cemento, de las resistencias mecánicas del hormigón, de la adherencia pasta árido, y del estado general del hormigón. La presencia de áridos reactivos, susceptibles de sufrir el ataque de los álcalis, aumenta la probabilidad de daño ocasionada por la formación de etringita.

-Parece que la expansión ocurre cuando los cristales de las fases hidratadas crecen alrededor de las partículas anhidras interaccionando los unos con los otros, o con el material que los rodea. Un ejemplo es la formación de hidroxido calcico: este compuesto produce expansión cuando se forma a partir de $\mathrm{CaO}$, pero no cuando se forma por liberación de iones $\mathrm{Ca}^{2+}$ y cristalización subsiguiente desde la fase líquida del sistema poroso. La etringitae parece comportarse de manera similar, aunque existen algunas diferencias todavia no explicadas: cuando se forma por hidratacion del $\mathrm{C}_{3} \mathrm{~A}$ o del $\mathrm{C}_{4} \mathrm{~A}_{3} \overline{\mathrm{S}}$, la etringita puede generar expansión; por otra parte, su formación dentro de la pasta puede ser, o no, expansiva. Este fenómeno se discutirá posteriormente.

-La recristalizacion de un cristal procedente de un lugar determinado en otro sitio, por razones termodinámicas y espaciales, no es un proceso expansivo. [ $\mathrm{El}$ ejemplo del crecimiento de las estalagmitas y las estalactitas de $\mathrm{CaCO}_{3}$ en una cueva es igualmente un ejemplo de un proceso no expansivo].

-La presión de cristalizacion existe como un fenómeno relacionado con la expansion; sin embargo, no es aplicable a todas las situaciones. Dado que este punto es motivo de controversia, a continuacion se analiza con algo más de detalle:

La expansión del hormigón ha sido frecuentemente explicada en términos de presión de cristalización de la etringita - la presión ejercida por los cristales de etringita encontrados en fisuras o en huecos alrededor de los áridos-. Nosotros no suscribimos este punto de vista, siendo varios los argumentos que justifican esta opinión en contra $(3,4)$.

En primer lugar, durante la precipitación de un sound concrete. Expanding forces will deteriorate the concrete matrix more at early stages of properties development than at later stages. Thus, formation of ettringite in hardened concrete may or may not cause expansion.

-Substantial amounts of ettringite can form within concrete without causing expansion and cracking. The amount of such non-deleterious ettringite depends, among others on $w / c$, concrete strength, paste-toaggregate bond (aggregate effect), homogeneity of the paste, and soundness of the concrete. Presence of alkali reactive aggregate will, ceteris paribus, increase the probability of damage caused by ettringite formation.

-It seems that expansion occurs when hydrate crystals grown around radial unhydrous particles impinge on each other or the surrounding material. An example is formation of calcium hydroxide: it causes expansion when formed from $\mathrm{CaO}$ but not when formed by release of $\mathrm{Ca}^{2+}$ ions and subsequent crystallization from pore solution. Ettringite seems to behave similarly, but there are some unresolved differences: when formed by hydration of $C_{3} A$ or $C_{A} A_{3} \bar{S}$, ettringite may lead to expansion; on the other hand, its formation within the paste may or may not be expansive. This phenomenon will be discussed later.

-Recrystallization of a crystal from a certain fixed space into another, thermodynamically or otherwise more prefered locality, is a non-expansive process. [Example: growth of stalagmites/stalactites of $\mathrm{CaCO}_{3}$ in a cave is a non-expansive process.]

-Crystal growth pressure does exist as an expansionrelated phenomenon; however, it is not applicable in all situations. Because this issue is controversial, let's discuss this phenomenon in somewhat more detail:

The expansion of concrete has often been explained in terms of ettringite crystallization pressure - pressure exerted by ettringite crystals found in cracks or in gaps around the aggregate. We do not subscribe to this view and there are several arguments against it (e.g.,3,4).

First, during precipitation of a crystalline compound 
compuesto cristalino desde una disolución, la presión ejercida sobre sus alrededores -la denominada presión de cristalizacion- requiere las condiciones termodinámicas siguientes:

-La fase que precipita debe encontrarse bajo presión

- El producto de las actividades de la fase que precipita cebe ser mayor en la disolución que en una disolución saturada (supersaturacion).

Para Taylor (6), en lo que a la cristalización de la etringita respecta, según la ecuación [1], y suponiendo condiciones ideales de crecimiento isotrópico y un grado de supersaturacion de $\mathrm{K} / \mathrm{Ks}=2$, la presion de cristalización P sería igual a 3,1 MPa. Ello se deduce de las siguientes expresiones [2 y 3] : from a solution, the pressure exerted on its surrounding - the so-called crystallization pressure requires the following thermodynamic conditions:

-The entire precipitating phase must be under pressure.

-The activity product of the precipitating phase in the solution must be larger than

in the saturated solution (super-saturation).

Per Taylor (6), for crystallization of ettringite according to eq. [1], and assuming (unrealistic) isotropic growth and the degree of supersaturation to be $K / K s=2$, the crystallization pressure $P$ would be equal 3.1 MPa. This follows from expressions [2] and [3]:

$$
\begin{gathered}
6 \mathrm{Ca}^{2+}+2 \mathrm{Al}(\mathrm{OH})^{4}+4 \mathrm{OH}^{-}+3 \mathrm{SO}_{4}{ }^{2-}+26 \mathrm{H}_{2} \mathrm{O}=\mathrm{C}_{6} \mathrm{AS}_{3} \mathrm{H}_{32} \\
\mathrm{P}=\mathrm{RT} / \mathrm{V} \times \ln (\mathrm{K} / \mathrm{Ks}) \\
\mathrm{K}=\left(\mathrm{Ca}^{2+}\right)^{6} \times\left(\mathrm{Al}(\mathrm{OH})^{4-}\right)^{2} \times\left(\mathrm{OH}^{-}\right)^{4} \times\left(\mathrm{SO}_{4}{ }^{2-}\right)^{3}
\end{gathered}
$$

donde $\mathrm{P}$ es la presión en $\mathrm{MPa}, \mathrm{T}$ es la temperatura en ${ }^{\circ} \mathrm{K}$, $R$ es la constante de los gases $\left(8,3 \mathrm{~J} \cdot \mathrm{K}^{-1} \cdot \mathrm{mol}^{1}\right)$, $V$ es el volumen molar $\left(\mathrm{m}^{3} \cdot \mathrm{mol}^{-1}\right), \mathrm{K}$ es el producto de las actividades, $\mathrm{Ks}$ el producto de las actividades a saturación (producto de solubilidad), y $\mathrm{K} / \mathrm{Ks}$ el grado de supersaturacion.

Como previamente se estableció, todos los cristales de etringita localizados en un volumen dado, tienen que estar sometidos a una presión idéntica. Si este no es el caso, todos los cristales que no están bajo presión crecerán hasta que el producto de las actividades $\mathrm{K}$, de la etringita en la disolución, descienda hasta alcanzar los valores correspondientes a la solución saturada, $\mathrm{Ks}$; 0 , en el caso de que la supersaturacion se mantenga de algún modo constante, hasta que los cristales afecten a la pasta que los rodea. De todo esto surgen las siguientes preguntas: ¿Cómo mantener la necesaria supersaturación? ¿Cómo se detiene la nucleacion y el crecimiento de los cristales si sólo pueden crecer bajo presión?

En trabajos experimentales con disoluciones supersaturadas, se suele observar que la nucleacion y el crecimiento de cristales de forma heterogenea son muy difíciles de evitar (sobre las paredes de los recipientes, pequeñas gotas o burbujas, o en otras superficies). Por lo tanto, en sistemas como las pastas de cemento, morteros y hormigones, con todas las superficies reactivas y defectos presentes, es muy improbable mantener disoluciones supersaturadas y evitar nucleaciones heterogéneas. Teniendo en cuenta todo esto, parece difícil comprender cómo podrían where $P$ is pressure in $M P a, T$ is temperature in ${ }^{\circ} \mathrm{K}, R$ is the gas constant $\left(8.3 \mathrm{~J} . \mathrm{K}^{-1} \cdot \mathrm{mol}^{-1}\right), V$ is the molar volume $\left(\mathrm{m}^{3} . \mathrm{mol}^{-1}\right), K$ is the activity product, $K$ s activity product at saturation, and $K / K s$ the degree of supersaturation.

As stated above, all ettringite crystals in the local volume element have to be under identical pressure. If this is not the case, all crystals that are not under pressure will grow until the activity product of the ettringite in solution, $K$, decreases to that corresponding to the saturated solution, Ks; or, in case supersaturation is somehow kept constant, until the crystals impinge on the surrounding paste. This prompts the questions: How to maintain the necessary super-saturation? How is the nucleation and crystal growth suppressed so only crystals under pressure can grow?

In experimental work with supersaturated solutions it is generally experienced that heterogenous nucleation and crystal growth are very difficult to avoid (on container walls, small bubbles or droplets, and other surfaces). Therefore, in systems like cement pastes, mortars and concretes, with all the reactive surfaces and defects present, it is very unlikely to maintain super-saturated solutions and avoid heterogeneous nucleation. Taking this into consideration, it appears difficult to understand how could conditions for the development of crystallization pressure in relation to 
prevalecer en el hormigón (material extremadamente heterogéneo) durante meses, e incluso años, las condiciones para el desarrollo de la presión de cristalización en lo que respecta a la "formación de la etringita retrasada". Además, muchos años de experiencia demuestran que las fisuraciones, delaminaciones, o descamaciones de rocas naturales o materiales artificiales, generalmente no son debidas a la simple precipitación de cristales desde disoluciones (19). Nosotros, no encontramos suficientemente persuasiva la fotografia de Diamond (20), que muestra una partícula de mica supuestamente deslaminada por la deposición de etringita secundaria (Figura 7); el propio autor reconoce no estar seguro cuando afirma que " parece" que la etringita " aparentemente" deslaminó la mica. La partícula de mica podría también haber sido alterada por la expansión de la pasta, habiendo recristalizado la etringita posteriormente en el espacio disponible.

Otro argumento en contra del mecanismo de expansión relativo a la presion de cristalizacion, nace en la observación de la anchura de los huecos que rodean por completo a las partículas de áridos (y que más o menos se encuentran llenos de etringita). Dichos espacios son proporcionales al tamaño de los áridos (4). Parece que, inconscientemente, el primero en dar a conocer este fenómeno fue H. Insley en 1966 (21) quien escribió:".. la etringita estaba presente alrededor de los áridos en forma de finos recubrimientos; los recubrimientos más gruesos se encontraban sobre los áridos más grandes". Para Diamond (20), tales huecos no se forman y, desde luegro, nn están relacionados con el tamaño del árido. Sin embargo, este autor nunca usó en sus trabajos la microscopía de fluorescencia, que hace la identificación no sólo posible, sino mas sencilla. Posteriormente se incidirá en este fenómeno.

El tercer argumento en contra de la teoría de la presión de cristalización radica en el hecho de no observar fisuras radiales procedentes de los poros completamente rellenos de etringita. Si la presión de cristalización jugara un papel destacado en el mecanismo de expansión, tales poros rellenos de etringita se comportarían como una partícula expansiva que produciria un modelo de fisuración como el que se muestra en la Figura 2 .

\section{DEF y expansión}

Ya se mencionó anteriormente que tanto el trabajo de laboratorio como los datos de campo confirman la existencia de una expansión relacionada con el tratamiento térmico de la pasta. Común a todos los datos (obtenidos sobre morteros $\mathrm{u}$ hormigones curados térmicamente a temperaturas que superan un "delayed ettringite formation" prevail in concrete, an extremely heterogeneous material, for months or even years. Also, many years of experience show that cracking, delamination, or scaling of natural rocks or man-made materials is usually not caused by simple precipitation of crystals from solutions (e.g., 19). We find Diamond's photograph showing a mica particle supposedly delaminated by deposition of secondary ettringite non-persuasive (Figure 7, ref.20); the author himself is not sure when he states that "it appears" that ettringite "apparently" delaminated mica. The mica particle might as well have been disrupted by the paste expansion and the ettringite recrystallized in the available space later.

Another argument against the crystallization pressure mechanism of expansion is the observation that the width of the gaps completely surrounding the aggregate particles (and more or less completely filled with ettringite). Are proportional to the size of the particles (4). It seems that, unknowingly, the first one to report this phenomenon was H.Insley in 1966 (21): "... the ettringite was present as thin linings of aggregate sockets, the thicker linings being on the sockets of the larger aggregate pieces". Per Diamond (20), such gaps do not form and are not related to aggregate size. However, he never used the fluorescent light technique that makes identification simple and possible. More about this phenomenon later.

The third argument against crystallization pressure is the fact that no cracks are seen radiating out from the often completely ettringite-filled pores. If crystallization pressure were to play a role, such a filled pore would behave in principle like an expanding particle and a crack pattern around the pore similar to that shown in Figure 2 would be expected.

\section{Expansion and DEF}

We mentioned above that both field data and laboratory work confirm the existence of heat-related paste expansion. Common to all above data (obtained on mortars or concretes heat cured at temperatures above a certain temperature) is the presence/ formation of ettringite in the paste, followed by expansion and 


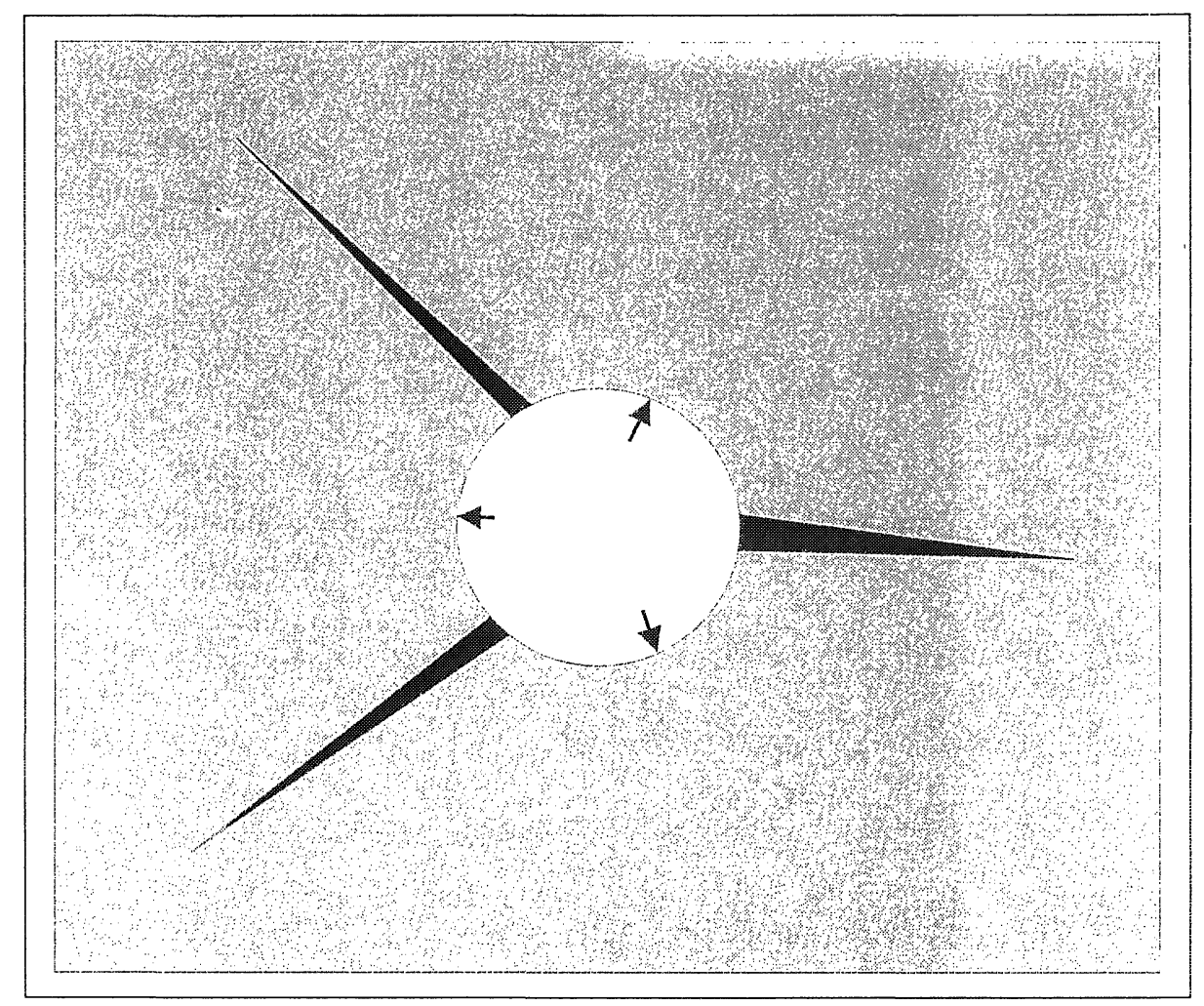

Fig. 2.- Esquema de partícula expandiéndose en la matriz Las fisuras se propagarian radialmente desde la particula (5).

Fig. 2.- Schematics of particle expanding relative to the matrix. Cracks are radiating out of the particle (5).

determinado nivel) es la presencia/formación de etringita en la pasta, seguida por una expansión y fisuración de las muestras durante un almacenaje con humedad (5). La formación de tal etringita, una vez enfriada la muestra, es perceptible posteriormente en poros, fisuras y huecos/fisuras alrededor del árido.

Las observaciones citadas se pueden explicar como se indica a continuación:

La etringita se hace inestable a temperaturas que sobrepasan los $60-70^{\circ} \mathrm{C}$. Las dos posible consecuencias de un tratamiento térmico a estas temperaturas son: (i) descomposición de la etringita formada por la reacción entre el $\mathrm{C}_{3} \mathrm{~A} / \mathrm{C}_{4} \mathrm{AF}$ y los sulfatos disueltos durante las primeras edades de la hidratacion, y/o (ii) la no formación de etringita.

La inestabilidad de la etringita, así como la formación de etringita retrasada, implica cambios en la concentración iónica de la disolución del sistema poroso. Concretamente, las concentraciones de sulfatos y $\mathrm{OH}^{-}$parecen estar fuertemente ligadas a la presencia de álcalis. Es por ello que a continuación se incide con más detalle en este punto. subsequent cracking of the samples during moist storage (5). Formation of such ettringite upon cooling is later noticeable in pores, cracks and gaps/cracks around the aggregate.

The above observation may be explained as follows:

\section{Ettringite becomes unstable at temperatures} exceeding 60 to $70^{\circ} \mathrm{C}$. The two possible result of heat treatment at or above these temperatures are: (i) decomposition of the ettringite formed by the reaction between $C_{3} A / C_{A} A F$ and the dissolved sulfates during the early hydration, and/or (ii) no further formation of ettringite.

The instability of ettringite as well as the formation of delayed ettringite involves changes in the ionic concentration of the pore solution and, in particular, the sulfate and $\mathrm{OH}$ concentrations seem to be strongly related to the presence of alkalis. Lets discuss the issue of eitringite stability in the presence of alkalis in more detail. 
La región de estabilidad de la etringita, dentro del sistema $\mathrm{CaO}-\mathrm{Al}_{2} \mathrm{O}_{3}-\mathrm{CaSO}_{4}-\mathrm{H}_{2} \mathrm{O}$ a temperatura ambiente, fue determinada por Jones (22). Este autor, junto con Berger (23) estudiaron también el mencionado sistema cuaternario en presencia de álcalis, concluyendo que la etringita se descompone en soluciones conteniendo más del $2,7 \%$, en peso, de $\mathrm{Me}_{2} \mathrm{O}(\mathrm{Me}=\mathrm{Na}, \mathrm{K}, \mathrm{Li})$.

Las opiniones en torno a este sistema a temperaturas elevadas, difieren; aunque las diferencias se han atribuido, entre otras cosas, al uso de condiciones experimentales diferentes. Por ejemplo, Odler (24) encontró que los curados a alta temperatura implican la desaparición de la etringita en períodos muy cortos de tiempo; él no detectaba ninguna etringita a $95^{\circ} \mathrm{C}$. Lieber (25), sin embargo, discute la formación de etringita que precipita en disoluciones acuosas a $90^{\circ} \mathrm{C}$. Brown y Bothe (26) encuentran etringita a la temperatura de $80^{\circ} \mathrm{C} \mathrm{y}$, además, demuestran que su formación es más favorable en disoluciones con bajos contenidos en álcalis. Estos autores concluyeron que el efecto combinado de los álcalis y la temperatura producen un retraso en la formación de la etringita y una aceleración en la reacción de hidratación del $\mathrm{C}_{3} \mathrm{~S}$, generando, así, una situación que permite que sulfatos y aluminatos puedan incorporarse a la estructura del gel C-S-H de forma que se impide la formación de etringita. Finalmente, Mehta (27) observó que la descomposición térmica de la etringita bajo condiciones de sequedad comenzaba a $93{ }^{\circ} \mathrm{C}$, siendo estable a temperaturas inferiores. Más recientemente, Damidot y Glasser (28), basándose en unos estudios de solubilidades de equilibrio del mencionado sistema, concluyeron que la presencia de los iones potasio o sodio modifica drásticamente los campos de estabilidad de los diferentes hidratos presentes en el sistema. También confirmaron la enorme influencia de la temperatura en el sistema $\mathrm{CaO}-\mathrm{Al}_{2} \mathrm{O}_{3}-\mathrm{CaSO}_{4}-\mathrm{H}_{2} \mathrm{O}$ de manera que: a temperaturas por encima de $45^{\circ} \mathrm{C}$, el monosulfoaluminato se hace más estable a expensas de la etringita; sin embargo, la etringita permanece estable en un amplio rango de concentraciones de sulfato y de pH. Los autores demuestran finalmente que sólo la etringita puede estar en equilibrio con disoluciones acuosas de $\mathrm{pH}$ inferior a 11. Datos recientes aportados por Lewis y Scrivener (29) demuestran que cuando se aumentan los niveles de álcalis, adicionados como $\mathrm{KOH}$, se produce un espectacular aumento de la expansión de los morteros como consecuencia de la expansión de las pastas en ausencia de cualquier reacción árido-álcali (ASR). Estos resultados parece que confirman el hecho, previamente mencionado de que, a temperaturas elevadas, el gel C-S-H puede captar cantidades superiores de sulfatos $(26,30)$. El mecanismo de captación y liberación de $\mathrm{SO}_{4}{ }^{2-}$ por el gel C-S-H no se ha llegado a comprender totalmente.
The region of stability of ettringite within the system $\mathrm{CaO}-\mathrm{Al}_{2} \mathrm{O}_{3}-\mathrm{CaSO}_{4}-\mathrm{H}_{2} \mathrm{O}$ at ambient temperature was determined by Jones (e.g.,22). He and Berger (23) also studied the above system in the presence of alkalis and concluded that ettringite decomposes in solutions containing more than $2.7 \mathrm{wt}$.\% of $\mathrm{Me}_{2} \mathrm{O}(\mathrm{Me}=\mathrm{Na}, \mathrm{K}, \mathrm{Li})$.

Opinions about the behaviour of this system at elevated temperatures differ, however, this being related, among others, to use of different experimental conditions. For example, Odler (24) found that high-temperature curing involves disappearance of ettringite in very short periods of time; he did not detect any ettringite at $95^{\circ} \mathrm{C}$. Lieber (25), on the other hand, discusses formation of ettringite from aquous solutions at $90^{\circ} \mathrm{C}$. Brown and Bothe (26) report formation of ettringite at temperatures as high as $80^{\circ} \mathrm{C}$ and found its formation to be more favourable in solutions low in alkalies. They concluded that the combined effect of alkali and temperature leads to retardation of ettringite formation and acceleration of $\mathrm{C}_{3} S$ hydration, thus enabling a mechanism by which sulphates and aluminates could be incorporated in the structure of the $\mathrm{C}-\mathrm{S}-\mathrm{H}$ gel in a way that prevents formation of ettringite. Finally, Mehta (27) observed that ettringite decomposition during heating under dry conditons started at $93^{\circ} \mathrm{C}$, while being stable at temperatures below. More recently, Damidot and Glasser (28), based on equilibrium solubility studies of the system, concluded that the presence of sodium or potassium ions drastically modifies the stability domains of the different hydrates present in the system. They also confirmed that temperature influences the $\mathrm{CaO}-\mathrm{Al}_{2} \mathrm{O}_{3}-\mathrm{CaSO}_{4}-\mathrm{H}_{2} \mathrm{O}$ system: at temperatures above $45^{\circ} \mathrm{C}$, monosulphoaluminate becomes more stable at the expense of ettringite; however, ettringite remains stable in a wide range of sulphate concentrations and $\mathrm{pH}$. They report that only ettringite can be in equilibrium with aqueous solutions having $\mathrm{pH}$ less than 11. Recent data by Lewis and Scrivener (29) show that increased level of alkali, added as $\mathrm{KOH}$, leads to dramatic increase of mortar expansion due to paste expansion in absence of any ASR. These results seem to support the previously reported fact that, at elevated temperatures, C-S-H may uptake increased amounts of sulfate (e.g., 26, 30). The mechanism of uptake and release of $\mathrm{SO}_{4}^{2-}$ by $\mathrm{C}-\mathrm{S}-\mathrm{H}$ is not fully understood. 
Este tema constituye un interesante objetivo de futura investigación.

Todos los datos extraídos de la literatura, como se puede ver, muestran que con elevados contenidos de álcalis se necesitan mayores concentraciones de aluminatos y sulfatos para que la etringita permanezca estable. De esta manera, la existencia combinada de los fenómenos ASR y DEF puede explicarse desde el punto de vista de la disponibilidad de álcalis: En presencia de áridos reactivos , la alcalinidad de la disolución del sistema poroso desciende, de aquí que aumente la estabilidad de la etringita que entonces puede formarse en la pasta y posteriormente recristalizar en áreas debilitadas por el efecto del ASR. En ausencia de ASR, la alcalinidad permanece más alta, de manera que las condiciones para la formación de etringita retrasada son menos favorables.

Con posterioridad, durante el almacenamiento del hormigón o una vez que éste ya se ha puesto en servicio, a temperatura ambiente y con altos contenidos de humedad, la etringita se forma y recristaliza con lentitud, y se distribuye íntimamente dentro del gel C-S-H de la pasta de cemento (7); esto, a su vez, conduce a la expansión de la pasta, generando la aparición de fisuras periféricas alrededor del árido, y fisuración del hormigón endurecido. Según la interpretación de los últimos datos de Karen Scrivener, la driving force ("fuerza impulsora") para la expansión es la diferencia entre la cantidad de sulfatos incorporados al gel C-S-H y la concentración de ión sulfato en la disolución del sistema poroso (29). Hay que destacar que esa expansión ocurre, incluso, en ausencia de áridos. Todo esto apoya la opinión de que es la pasta en sí misma, más que la etringita depositada en los huecos, la que expande durante el fenómeno DEF.

Una representación esquemática del mecanismo de expansión por la DEF fue sugerido por Taylor (6). Figura 3.
This is an area in need of further detailed mechanistic investigation.

All above literature data show that at high alkalinity increased concentration of aluminate and sulfate ions is required for ettringite to remain stable. Thus, the combined occurance of $A S R$ and DEF can be explained in terms of alkali availability: In the presence of alkalireactive aggregate, alkalinity of the pore solution decreases, hence increasing the stability of ettringite which then can form in the paste and later reform in areas weakened by the ASR damage. In the absence of $A S R$, alkalinity remains higher, thus formation of delayed ettringite is less favourable.

Subsequently, during storage or service of the concrete at ambient temperature and high moisture, ettringite slowly forms and reforms, and is intimately distributed within the C-S-H of the cement paste (e.g.,7); this, in turn, leads to expansion of the paste, thus causing formation of peripheral cracks (gaps) around the aggregate, and cracking of the hardened concrete. According to Scrivener's interpretation of her latest data, the driving force for the expansion is the difference between the amount of sulfate incorporated in $\mathrm{C}-\mathrm{S}-\mathrm{H}$ and the $\mathrm{SO}_{4}{ }^{2-}$ concentration of the pore solution (29). Please note that expansion occurs even in the absence of aggregate (thus gaps around the aggregate); this supports the view that it is the paste itself, rather than the ettringite deposited in the gaps, that expands during $D E F$.

A schematic representation of $D E F$ expansion mechanism was suggested by Taylor (6), see Figure 3.

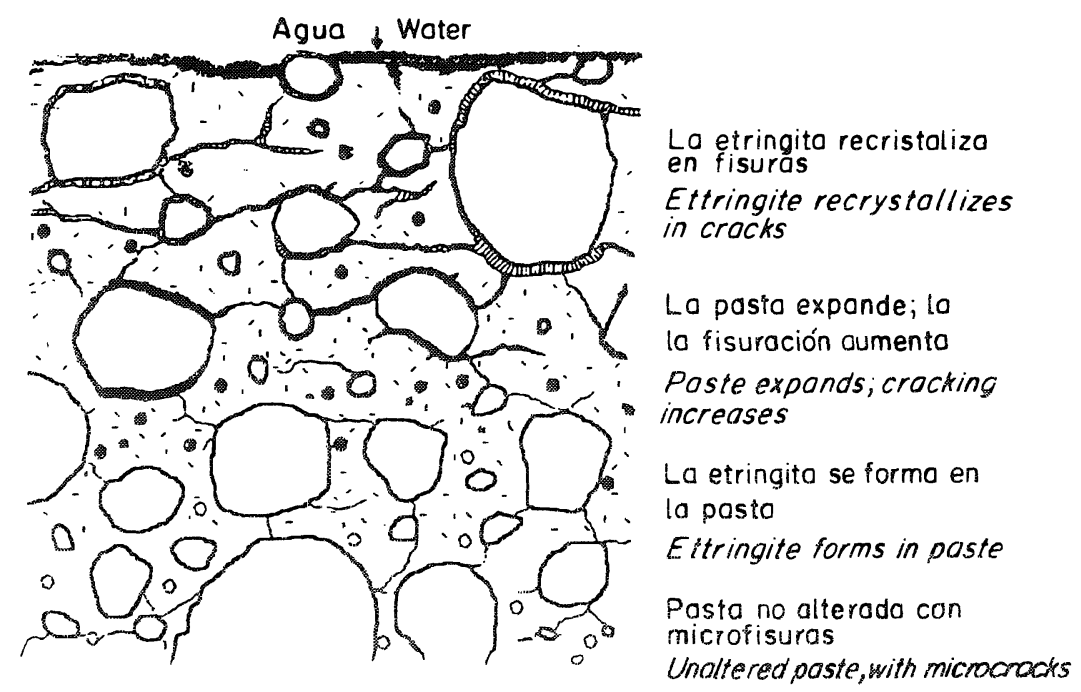

Fig. 3.- Mecanismo de expansión por DEF en morteros.

Fig. 3. - Mechanism of DEF expansion in mortar. 


\section{CAUSAS DEL FENÓMENO DEF}

Hay tres factores básicos que influen en la existencia y el progreso del fenómeno DEF:

-Composición de los componentes del hormigón

-Condiciones de curado

-Condiciones de exposición ambiental.

Existen otros parámetros que tambien pueden jugar un papel importante en la existencia del fenómeno, pero sería necesario investigar más en este tema, dado que aún son muchas las incógnitas que permanecen.

\section{La composición del hormigón:}

Los parámetros composicionales que pueden influir en la DEF son:

-Tipo de árido y granulometría

-Composición del cemento y proporción en la mezcla

-Tipo y contenido de adiciones

-Relación agua-cemento

-Contenido de aire y porosidad del hormigón

La mineralogía del árido es importante en el sentido que ésta influye sobre la zona interfacial, de manera que puede impedir o exacerbar la fractura de la interfase pasta-árido y, por comsiguiente, controlar la expansión y la fisuración. Ha sido inicialmente supuesto por algunos autores que, en ausencia de áridos, no hay expansión. Sin embargo, basándonos en observaciónes en torno a la formación de huecos alrededor de los áridos, nosotros hemos considerado que la pasta expande, independientemente de la presencia de áridos, lo cual, es hoy día, una hipótesis generalmente aceptada (8). Se ha escrito que el tipo de árido afecta a la existencia, o no y, en su caso, a la intensidad con que se da el fenómeno DEF, especialmente cuando la calidad del árido induce a la reacción árido-álcali [ASR] (9). En ausencia de tal mecanismo combinado, el efecto del árido está más relacionado con la calidad de la pasta y con la unión interfacial entre la pasta y el árido.

La composición del "cemento" ha sido extensamente estudiada por Lawrence (8) quien, examinando 40 cementos y, usando el análisis de regresión, encontró correlaciónes lineales de pendientes positivas entre la expansión (a 400 y 800 días) y los contenidos de $\mathrm{SO}_{3}$, álcalis totales, $\mathrm{Na}_{2} \mathrm{O}, \mathrm{y} / \mathrm{o} \mathrm{MgO}$ y correlaciones con pendientes negativas $\mathrm{o}$ inexistencia de correlacion entre la expansión y los contenidos de $\mathrm{K}_{2} \mathrm{O}$ y/o $\mathrm{Fe}_{2} \mathrm{O}_{3}$. La correlación lineal de pendiente positiva se observó también para el contenido de $\mathrm{C}_{3} \mathrm{~A}$ y para el tamaño de partícula del cemento, sin embargo, en estos casos, los

\section{CAUSES OF DEF}

There are three basic factors influencing the occurance and progress of $D E F$.

-composition of the concrete components,

-curing conditions, and

-environmental exposure.

Other parameters may play a role also; some of the details are not well explored at this time, however.

\section{Concrete composition:}

The following compositional parameters may influence $D E F$ :

-Aggregate type and grading

-Cement composition and amount

-Type and amount of mineral admixture

-Water-to-cement ratio

-Air content and porosity of concrete

The mineralogy of the aggregate is important in that it influences the interfacial bond, thus may prevent or excerberate breakage of the paste-aggregate bond, and consequently control the expansion and cracking. It has been initially assumed by some that in the absence of aggregate expansion does not occur. However, based on the observation of the formation of complete gaps around the aggregate, we have argued from the beginning that the paste is expanding independently of the presence of aggregate and this is now generally accepted (e.g., 8). It has been reported that the type of aggregate influences the occurance and severity of $D E F$, especially when aggregate quality leads to $A S R$ (e.g.,9). In the absence of such combined mechanism, the effect of aggregate is related to the quality of the paste and interfacial bond between the paste and the particular aggregate.

The composition of the "cement" has been studied extensively by Lawrence (8) who examining 40 cements and, using regression analysis, found positive linear correlation between the expansion (at 400 and 800 days) and $\mathrm{SO}_{3}$, total alkali, $\mathrm{Na}_{2} \mathrm{O}$, and/or $\mathrm{MgO}$ contents, but negative or no correlations between expansion and $\mathrm{K}_{2} \mathrm{O}$ and/or $\mathrm{Fe}_{2} \mathrm{O}_{3}$ contents. Positive correlation was observed also for $C_{3} A$ content and particle size of the cement, however the correlation coefficients were lower (0.2-0.4 compared to 0.6-0.7). The threshold values above which DEF seems to be 
coeficientes de correlación eran inferiores con respecto a los mencionados anteriormente $(0,2-0,4$ frente a $0,6-0,7)$. Los valores umbrales por encima de los cuales la DEF parece ser posible son: $2,5 \% \mathrm{SO}_{3}$ y $1,0 \% \mathrm{MgO}$-lo que cubre la mayoría de los cementos producidos en el mundo. Los efectos del $\mathrm{MgO}$ y del contenido de cemento son, por ahora, inciertos. Sería necesario contar con datos adicionales.

Recientemente se ha sostenido $(1,31)$ que la forma y cantidad del azufre en el clínker puede conducir a la DEF. Además, se incide en que los clínkeres hechos en hornos que usan productos residuales, tales como llantas usadas y productos químicos de desecho, como complemento a los combustibles naturales, son la causa de algunos (aunque poco documentados) casos de DEF. En lo que respecta a la opinión de los autores del presente trabajo, la mayoría de los clínkeres producidos en el mundo contienen sulfatos en forma de sulfatos alcalinos $\left(\mathrm{K} \overline{\mathrm{S}}, \mathrm{K}_{3} \mathrm{NS}_{4}\right)$ o alcalinotérreos $\left(\mathrm{C}_{2} \mathrm{KS}_{3}\right)$, más pequeñas cantidades de azufre que pueden encontrarse como sustituciones en algunas de las fases del clínker, especialmente en los silicatos cálcicos ( $\overline{\mathrm{S}}$ que sustituye a $\mathrm{Si})$.

El sulfato cálcico o anhidrita $(\mathrm{C} \overline{\mathrm{S}})$ no es un compuesto típico de los clínkeres industriales, ni siquiera de los que pueden considerarse con altos contenidos en azufre. Es, incluso, discutible si la formación de anhidrita bajo las condiciónes de trabajo de los hornos usados en la producción de clinker es termodinamicamente posible. Aun cuando la formación de anhidrita fuera posible, la cantidad de sulfato en el clínker tendría que estar por encima del $2 \%$ para que este compuesto se formara, y estos niveles no serían, por sí mismos, una prueba segura o una razón del fenómeno DEF.

La afirmación de que el azufre del combustible perdura en el horno de cemento, trabajando a temperaturas por encima de $1.400^{\circ} \mathrm{C}$, no está suficientemente documentada y parece absurda. Los sulfatos procedentes de los combustibles, durante la cocción del clínker, llegan a formar parte de éste de la misma manera que lo hacen los sulfatos procedentes de otras fuentes (38).

Las adiciones, tales como las cenizas volantes, puzolanas naturales, escorias de alto horno, o el humo de sílice pueden impedir o disminuir la posibilidad para que se de el fenómeno de la DEF. De cualquier manera, pocos son los detalles que se conocen en torno al tema. Lo que si se sabe es que las adiciones activas, así como los inertes, mitigan el ataque externo de los sulfatos; así como también mejoran la microestructura de la interfase árido-pasta.

Los efectos de la "porosidad" no se han explorado possible are $2.5 \% \mathrm{SO}_{3}$ and $1.0 \% \mathrm{MgO}$-covering most cements produced worldwide. The effects of $\mathrm{MgO}$ and of the cement content are unclear at this time. Additional data are needed.

It has been claimed recently (1,31) that the form and amount of clinker sulfur may lead to DEF. Additionally, the claim is being made that clinkers made in kilns in which wastes, such as used tires and waste chemicals, are used to supplement natural fuels, are the reason for some, thus far undocumented cases of DEF. To the best of our knowledge, the majority of clinkers produced worldwide have sulfates present in the form of highly-soluble alkali $\left(K \bar{S}, K_{3} N \bar{S}_{4}\right)$ or calcium-alkali $\left(C_{2} K \bar{S}_{3}\right)$ sulfates, plus minor amounts of sulfate may be found as substitutions in some of the clinker minerals, especially in calcium silicates $\overline{(\bar{S}}$ substituting for Si).

Calcium sulfate anhydrite (CS) is typically not a compound found in industrial clinkers, not even in high-sulfur clinkers; it is even questionable whether formation of calcium sulfate anhydrite under the kiln condition used in clinker production is thermodynamically possible. Even if formation of anhydrite were possible, the amount of clinker sulfate would have to be well above $2 \%$ to form it, and this level would still not be by itself a sure indication of or reason for a "delayed" reaction.

The claim that waste fuel sulfur "survives" the cement clinker chemical reactor (cement kiln), operating at temperature well above $1.400^{\circ} \mathrm{C}$, is undocumented and preposterous. Sulfate from waste materials will during clinker burning become part of the clinker in the same manner as sulfate from other sources (38).

"Mineral admixtures" such as fly ash, pozzolans, slag, or silica fume may prevent or decrease the possibility for $D E F$, but little detail is available as of this date. However, mineral admixtures and fillers are known to mitigate external sulfate attack as well as to improve the paste-aggregate interfacial microstructure.

The effects of "porosity" are not well explored, but one 
concienzudamente, pero se podría esperar una minimización del fenómeno DEF si el transporte de especies iónicas, a través del sistema de poros, se decelera o se impide. Esto puede regularse en buena medida controlando la relacion agua/cemento y el adecuado procesado del hormigón.

\section{Condiciones de Curado:}

Las condiciones de curado constituyen el factor mejor explorado con respecto al fenomeno DEF. La experiencia acumulada en Finlandia (12), Alemania(14), Reino Unido $(8,17)$, etc. $y$, fundamentalmente, en USA (3b), muestra claramente que, al menos los siguientes parámetros, pueden influir en la DEF:

- Inicio del fraguado

- Secado

- Elevación de temperatura ( choque térmico)

-Temperatura máxima

-Tiempo de curado a la temperatura máxima

- Velocidad de enfriamiento

Los resultados muestran, y no es sorprendente, que los comienzos rápidos del fraguado conducen a más bajas resistencias y aumentan la probabilidad de existencia de DEF. Por otra parte, tiempos suficientemente largos permiten la formación de una etringita no expansiva (primaria) y un adecuado desarrollo de resistencias con anterioridad al tratamiento térmico. El tiempo recomendado para el inicio del fraguado oscila entre 2-4 horas.

En cuanto al tratamiento térmico es importante destacar que una excesiva velocidad de aumento de temperatura puede conducir a microfisuraciones, debido a las diferencias existentes en el coeficiente térmico de expansión del aire, el agua, el cemento y el árido, debilitando, así, la interfase entre la pasta y el árido. Las velocidades de calentamiento recomendadas están sobre $20^{\circ} \mathrm{C}$ por hora. Este valor puede diferir para diferentes cementos y diferentes contenidos de cemento.

La "temperatura máxima de curado" es el parámetro más importante individual que controla el fenómeno DEF (nótese que se hace referencia a la temperatura interior del elemento de hormigón, y no a la temperatura exterior). Debido al carácter exotérmico de las reacciones de hidratación (sobre $320 \mathrm{~kJ} / \mathrm{kg}$ ), y, dependiendo, de la cantidad y tipo de cemento usado, una cantidad considerable del calor de reacción evoluciona junto a la energía abastecida por el tratamiento térmico del curado. Ello puede hacer que la temperatura de curado se eleve por encima de lo would expect DEF to be minimized if easy transport of species through the pore system is decelerated or prevented. This can be controlled to a large degree by the $w / c$ and proper concrete processing.

\section{Curing Conditions:}

Curing conditions are the best explored factor with respect to DEF. Practical experience obtained in Finland (12), Germany(14), United Kingdom $(8,17)$ and elsewhere, primarily in the U.S.(e.g., $3 b)$, shows clearly that at least the following parameters mav influence DEF:

\section{-Preset time \\ -Dry-out \\ -Temperature rise (thermal shock) \\ -Maximum temperature \\ -Curing time at maximum temperature \\ -Cooling rate}

Available results show, and it is not surprising, that "short preset times" lead to lower late strength and increased probability of DEF. On the other hand, sufficiently long preset time allows non-expansive formation of ettringite (primary ettringite) and adequate bond/strength development prior to temperature rise. The recommended preset time is a minimum of 2-4 hours.

Temperature rise is important in that excessive rate of increase may lead to microcracking due to differences in thermal coefficient of expansion of air, water, cement and aggregate, thus weakening the interface bond between the paste and the aggregate. Recommended heating rate is about $20^{\circ} \mathrm{C}$ per hour. This rate may differ for different cement compositions and cement contents.

The" maximum temperature of curing" is the single most important parameter controlling DEF. Please note that the interior, not the exterior (!), temperature of concrete is the decisive factor. Due to the exothermic character of hydration reactions (about 320 $\mathrm{kJ} / \mathrm{kg}$ ), and depending on the amount and type of cement used, a substantial amount of reaction heat is evolved that, together with the energy supplied by the steam-curing, may raise the curing temperature well above that expected. Thus, the temperature needed for 
esperado. Así, la temperatura necesaria para lograr la descomposición de la etringita primaria se puede alcanzar fácilmente.

Ensayos de laboratorio han confirmado que el curado de muestras de hormigón a $100 \%$ de humedad relativa y por encima de $60^{\circ} \mathrm{C}$, puede ocasionar DEF. Bajo condiciones de producción industrial, durante la cual se pueden dar gradientes de temperatura en el hormigón fresco capaces de ocasionar tensiones mecánicas, la temperatura crítica puede ser, incluso, más baja. Se ha observado que hormigones microfisurados $u$ hormigones con una baja cohesión interfacial son más susceptible de sufrir el fenómeno DEF.

El tiempo "de curado" a la temperatura máxima puede influir en el grado de descomposición de la etringita, así como en otros importantes parámetros químicos o microestructurales.

El efecto de la velocidad de enfriamiento, si es que tiene algún efecto sobre la DEF, no ha sido estudiado.

\section{Exposición Ambiental:}

La posibilidad de que el fenómeno DEF se produzca por razones composicionales o de curado, no puede materializarse, a menos que el hormigón, mientras está en servicio, se exponga a la humedad adecuada durante largos períodos de tiempo. Así, los siguientes parámetros deberían ser tomados en consideración:

- Agua/Humedad

- Tiempo

- Temperatura

- Exposición Solar

- Carbonatación

Una condición previa para que el fenómeno DEF ocurra es la presencia de agua líquida dentro del hormigón. El agua participa en las reacciones de hidratación, permite el transporte de especies iónicas, y representa, aproximadamente, la mitad del volumen de la etringita. Se estima que una humedad relativa por encima del $80 \%$ es necesaria para que aparezca el fenómeno DEF

La experiencia también demuestra que el tamaño de la estructura de hormigón puede ser importante, porque la penetración del agua en la estructura, así como el transporte del líquido por el interior de ésta se controla básicamente por un mecanismo de difusión. En otras palabras, una estructura delgada puede deteriorarse a más velocidad que una estructura gruesa. También, humedades diferentes en partes diferentes de una estructura o elemento de hormigón puede generar un transporte de sulfatos alcalinos a la parte donde el agua evapora, agravando, así, el deterioro. decomposition of primary ettringite can easily be reached.

Laboratory tests have shown that curing of concrete specimens at $100 \% \mathrm{RH}$ and above $60^{\circ} \mathrm{C}$ may cause $D E F$. Under industrial production conditions during which temperature gradients in freshly set concrete may cause mechanical stresses, the critical temperature may be even lower. It has been observed that microcracked concrete, or concrete posessing lower initial interfacial bond, is more susceptible to $D E F$.

The length "of curing" at the maximum temperature may influence the degree of ettringite decomposition and other important chemical and microstructural parameters.

The effect of cooling rate, if any, on DEF is unexplored.

\section{Environmental Exposure:}

The potential for DEF, caused by the compositional and curing factors discussed above, cannot materialize unless the concrete is exposed to adequate moisture for extended periods of time during its service. Thus, the following parameters should be taken into consideration:

\section{-Water/humidity \\ -Time \\ -Temperature \\ -Sun Exposure \\ -Carbonation}

Liquid water inside the concrete is a precondition for DEF to proceed: water participates in the hydration reaction, enables transport of ionic species, and represents about half of the volume of ettringite. It is estimated that a relative humidity of above $80 \%$ is needed for DEF to proceed.

Practical experience also shows that size of the structure may be important, because ingress into and the transport of humidity within the structure is primarily diffusion controlled. In other words, a thin structure may deteriorate at a higher rate than a thick structure. Also, different humidities in different parts of a concrete structure/product may cause transport of alkali sulfates to the part where water evaporates, thus aggravating the deterioration. 
El tiempo, por otra parte, es esencial: el fenómeno DEF sigue una curva tipo $\mathrm{S}$ (32), con un período de inducción, un período de aceleración, y un período de deceleración en la expansión. Un hormigón en buen estado, normal en la actualidad, puede comenzar a deteriorarse en el futuro. La experiencia demuestra que el fenómeno de la DEF típico en el hormigón se da tras 2 a 6 años de exposición.

La velocidad de expansión y fisuración está controlada en gran medida por la temperatura ambiente. Como cualquier proceso químico, la DEF se ve acelerada con el incremento de la temperatura aunque el valor exacto de la energía de activación es desconocido. Desde el punto de vista del fenómeno DEF, y sin tomar en consideración el posible deterioro per el efecto "hielodeshielo", el clima frío y seco es preferible al clima cálido y húmedo.

También se ha observado que la energía solar puede aumentar la temperatura del hormigón (en el lugar de insolación directa) unos $30^{\circ} \mathrm{C}$ por encima de la temperatura ambiente. Tal aumento en la temperatura puede conducir a algún tipo de ataque interno por sulfatos. En un estudio de laboratorio, llevado a cabo en Canadá, se encontró que tres ciclos de calentamiento a temperaturas entre $21^{\circ}$ y $82^{\circ} \mathrm{C}$ eran suficientes para generar un severo daño en las muestras objeto de estudio debido al ataque interno de los sulfatos (33).

No está claro si un número alto de ciclos de calentamiento a temperaturas inferiores generaría tal ataque, pero es perfectamente creíble que ciclos de calor, inducidos por una intensa radiación solar en climas calidos y húmedos, puedan exacerbar el fenómeno DEF. La experiencia demostró que una serie de elementos de hormigón idénticos, expuestos a la luz del sol y orientados en el lado sur de una estructura, expandieron y fisuraron por efecto de la DEF mientras que los elementos en la sombra, orientados sobre el lado norte del edificio, se encontraban inalterados.

La carbonatación juega un papel secundario en tanto en cuanto puede iniciar o acelerar la descomposición de una etringita ya formada para dar carboaluminatos cálcicos insolubles y sulfatos solubles (34). Si este es el caso, la carbonatación puede ocasionar migración del sulfato, liberando a las partes no carbonatadas de la estructura, permitiendo, así, una expansión y fisuración continua.

\section{DETECCIÓN DEL FENÓMENO DEF}

Los cuatro aspectos principales que pueden usarse para la detección del fenómeno DEF son los siguientes:
Time is of essence: DEF follows an $S$-curve (32) with an induction period, accelerating period, and a decelerating period of expansion. A presently sound concrete may start to deteriorate in the future. Experience shows that typical DEF expansion in field concrete occurs after about 2 to 6 years of exposure.

The rate of expansion and cracking is controlled to a large extent by the ambient temperature. As a chemical process, DEF is accelerated by increased temperature but the exact value of the activation energy is unknown. From DEF point of view, and not taking into consideration possible freezing-thawing damage, cold and dry climate is preferable to a warm and humid climate.

It has also been observed that energy of sunlight may increase the concrete temperature by $30^{\circ} \mathrm{C}$ above ambient temperature. Such increase in temperature may lead to some sort of internal sulfate attack, as also implied by inconclusive laboratory studies in ('anada: three heating cycles between $21^{\circ}$ to $82^{\circ} \mathrm{C}$ ' were found to severely damage the specimens due to internal sulfate attack (33).

It is not clear whether a higher number of heating cycles at lower maximum temperature would lead to such an attack, but it is conceivable that temperature cycles induced by intense sun radiation in a hot and humid climate can exacerbate DEF. Field experience shows that otherwise identical concrete elements exposed to sunlight on the southern side of a structure expanded and cracked due to DEF while those in the shade on the northern side of the building were undamaged.

Carbonation plays a secondary role in that it may initiate or accelerate decomposition of already formed ettringite to form insoluble calcium carboaluminate and soluble sulfates (34). If this is the case, carbonation may cause migration of the released sulfate to uncarbonated parts of the structure. thus enabling continuous expansion and cracking.

\section{DEF DETECTION}

The four main features that can be used for detection of DEF are as follows: 
- Ausencia de fuentes externas de sulfatos

- Una historia de curado a alta temperatura

- Presencia de huecos rodeando completamente a los áridos

- Tamaño de los huecos proporcionales al tamaño de partícula

El primer punto es obvio, y la presencia o la ausencia de fuentes externas de sulfatos debería ser determinada por la evaluación de los datos históricos o experimentalmente en función de las necesidades. Usando técnicas químicas y de microscopía óptica, el deterioro del hormigón debido al ataque externo de sulfatos puede determinarse fácilmente. Los aspectos principales a investigarar son: fisuras paralelas a la superficie del hormigón, presencia de yeso y/o etringita en huecos, fisuras y pasta, y señales de disolución de la pasta de cemento.

Sobre los datos en torno al curado del hormigón a alta temperatura, el investigador debería observar las prácticas de trabajo en la planta de procesado de hormigón. Aunque hoy día, la determinación directa de la temperatura de curado parece ser posible mediante una evaluación de la microestructura del hormigón $(35,36)$. Por medio de la microscopía electrónica de electrones retrodifundidos (BSE), se pueden observar diferentes niveles de grises entre ciertas microestructuras formadas a diferentes temperaturas. Más concretamente, se pueden observar anillos de doble tonalidad que circundan todavía a las partículas de cemento anhidro. Esto es característico de hormigones curados a temperaturas elevadas.

Si se centra ahora la atención en los huecos alrededor de los áridos y en el tamaño de dichos huecos, no parece, en principio, que exista una manera lógica de explicar cómo la anchura de los huecos -y, por tanto, el tamaño de la capa de etringita- pueda estar controlada por el tamaño del árido. Sin embargo, se demostrará que la relación existente entre la anchura de los huecos y el tamaño de los áridos está de acuerdo con una expansión lineal homogenea de la pasta de cemento (37). Ello se demuestra esquematicamente en la Figura 4.

Se desprende de dicha Figura que, en el caso de una expansión homogénea, todos los puntos se separan los unos de los otros por un factor constante de $(1+e)$, donde e es la expansión lineal relativa:
-Absence of external sulfate source

-High-temperature curing history

-Presence of gaps completely surrounding aggregate

-Gaps width related to particle size

The first item is obvious, and presence or absence of external source of sulfate should be determined by evaluation of historical data and experimentation, as needed. Using chemical and optical techniques, concrete deterioration due to external sulfate attack can easily be determined. The main features to look for are: cracks parallel to the surface of the concrete. presence of gypsum and/or ettringite in voids, cracks, and paste, and signs of dissolution of cement paste.

For high-temperature curing data one should look into the concrete plant processing practices. However, direct determination of high-temperature curing seems now to be possible by evaluation of the concrete microstructure (e.g.,35,36). Using backscattered electron image (BSE) mode, one can observe gray level differences between certain microstructures formed at ambient versus increased temperatures; more specifically, one can observe two-tone rims surrounding still unhydrated cement particles, this being characteristic of concretes cured at elevated temperatures:

Let's now concentrate on the issue of the gaps around the aggregate and their width. There seems to be no logical way of explaining how can the width of the gap -and thereby the size of the ettringite layer-be controlled by the size of the aggregate particle. However, it will be shown that the relationship between the width of the gaps and the particle size is in agreement with a homogenous linear expansion of the cement paste (37). This is schematically shown in Figure 4.

It should be obvious from the figure that, in the case of an homogeneous expansion, all points move away from each other by a constant factor of $(I+\varepsilon)$, where $e$ is the relative linear expansion:

$$
\left|\mathrm{OA}^{\prime}-\mathrm{OB}^{\prime}\right|=|(1+e) \mathrm{OA}|-\left|(1+e) O B^{\prime}\right|=|(1+e)(\mathrm{OA}-\mathrm{OB})|
$$

Si nosotros podemos visualizar una partícula esférica de árido no expansivo y de radio $R$, embebida en una matriz de pasta de cemento (fenómeno parecido al del planeta Tierra -no expansivo- situado en un Universo
If we can visualize a spherical, non-expanding aggregate particle of radius $R$ imbedded in an expanding cement paste matrix (similar to the nonexpanding - Earth in an expanding liniverse. thus 

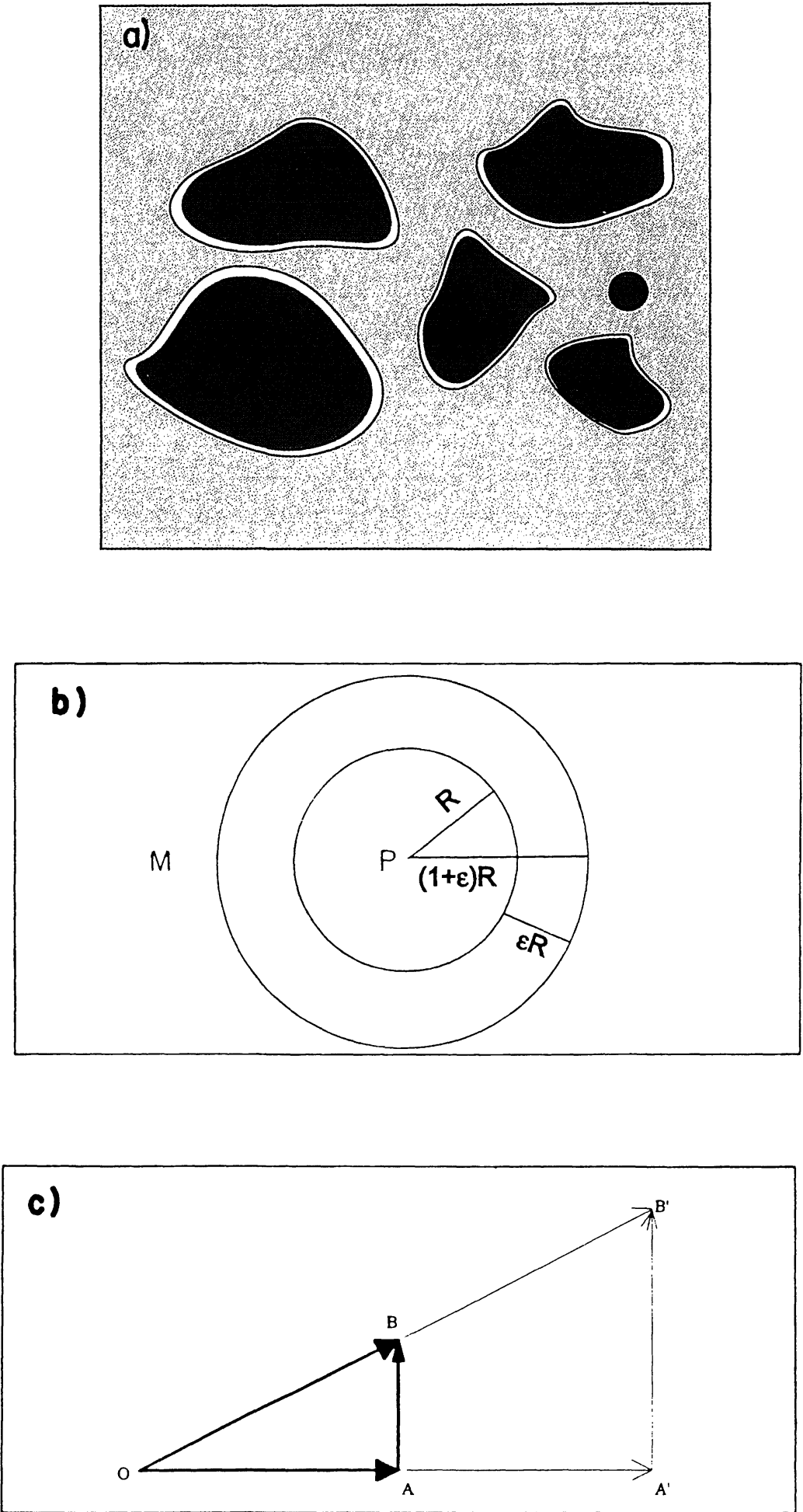

Fig. 4.-Representación esquemática de formación dehuecosen la periferia de laspartículas de árido $(4,37)$. (a) Representación gráfica de una matriz que expande un $10 \%$ respecto de las partículas inertes. La anchura del hueco es proporcional al tamaño del árido. (b) Essbozo de una matriz (M) expandiendo y desplazándose de la superficie de una partícula inerte (P) generando una brecha (G). (c) Representación vectorial de la expansión.

Fig.4.- Schematic representation of formation of peripheral cracks (gaps) around aggregate particles $(4,37)$. (a) Graphical representation of matrix expanding $10 \%$ relative to inert particles. Gap width is proportional to the particle size. (b) Sketch of a matrix (M) expanding away from the surface of an inert particle (P) leaving a gap $(G)$. (c) Vectorial representation of the expansion. 
expansivo, y en el que, consecuentemente, se va agrandando la distancia entre el centro de la Tierra y cualquier punto dentro de el Universo) entonces, con posterioridad a la expansión de la pasta, la interfase se desplaza de la superficie del árido en una distancia de $(1+\varepsilon) R$, creando una brecha alrededor de la partícula de árido; la anchura de esta brecha aumenta con el tamaño del árido. Esto ha sido experimentalmente probado por Johansen et.al. (4). Un ejemplo se puede observar en la Figura 5.

Los huecos alrededor del árido, ocasionados por la expansión citada, permiten la precipitación de etringita secundaria debido al proceso de recristalización previamente discutido. La Figura 6 representa una traviesa de ferrocarril hecha de hormigón y curada térmicamente que muestra espacios vacios circundando completamente las partículas de árido y en los que se ha depositado etringita.

Es importante poner énfasis y prevenir en contra de la práctica de determinar las causas de deterioro del hormigón, exclusivamente en base a modelos en torno a la fisuración observada en la superficie. Tales modelos no dicen nada sobre las múltiples causas posibles de fisuración, ni tampoco revelan la secuencia de los diferentes mecanismos.

Por medio de las técnicas de microscopía óptica y electrónica, un petrógrafo experimentado puede distinguir fácilmente entre ASR, DEF, y otros mecanismos de deterioro, y determinar la secuencia y el mecanismo de daño que predomina (Figuras 6 y 7). Por tanto el argumento de que DEF y ASR son a veces no distinguibles no está justificado.

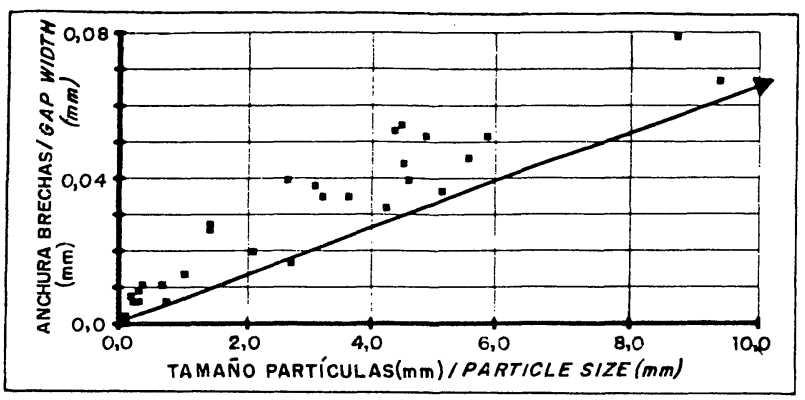

Fig. 5.- Anchura de las fisuras perifericas (brechas) cntre la matriz de pasta de cemento y las partículas de árido, en función del tamaño del árido. Traviesa de ferrocarril de hormigón pretensado curada al vapor. NOTA: Dado que una lámina delgada es una representación bidimensional de una partícula tridimensional, para cada diámetro de partícula hay un valor limite, mas bajo, de la anchura del hueco que es una función lineal del diámetro de la partícula. En la referencia (5) se pueden encontrar más detalles.

Fig.5.- Width of periferal cracks (gaps) between cement paste matrix and aggregate particles as a function of aggregate size. Steam-cured prestressed concrete railroad sleeper. NOTE: Because a thin section is atwo-dimensional representation of tree-dimensional particles, foreach particle diameter there is a lower boundary value for the gap width which is alinearfunction of the particle diameter. For more detailed explanation see (5). enlarging the distance between the center of the Earth and any point within the Universe) then, after the paste expansion, the paste interface moved away from the aggregate surface by a distance of $(1+\varepsilon) R$ creating a gap around the particle; the width of this gap is increasing with the aggregate size. This has been experimentally proven by Johansen et al (4) and is shown by an example in Figure 5.

The gaps around the aggregate caused by the above expansion enable precipitation of secondary ettringite due to the recrystallization process discussed above.

Figure 6 represents a heat cured concrete railroad tie showing gaps completely surrounding the aggregate particles and ettringite deposited in such gaps.

We would like to caution against determination of the cause of concrete deterioration solely on the basis of observed surface crack pattern. Such patterns do not say anything about the possible multiple causes of cracking, neither do they reveal the sequence of the different mechanisms.

Using optical and electron-optical techniques, an experienced petrographer can easily distinguish between ASR, DEF, and other mechanisms of deterioration, and to determine the sequence and prevailing mechanism of damage (figures 6 and 7). Thus the claim that DEF and ASR are sometimes indistinguishable is unwarranted.

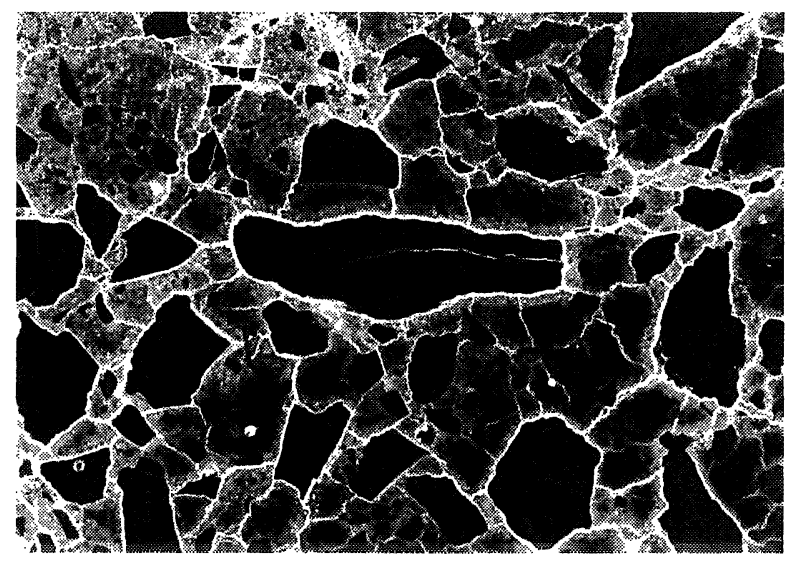

Fig. 6.-T'ípico modelo defisuración ocasionadopor la expansión de la pasta que genera el fenómeno DEF. Microscopía con lámpara de fluorescencia. Amplitud de campo: $9 \times 12,5 \mathrm{~mm}$.

Fig. 6.- Typical cracking pattern caused by DEF expansion of the paste. Fluorescent light. Field of view: $9 \times 12.5 \mathrm{~mm}$. 


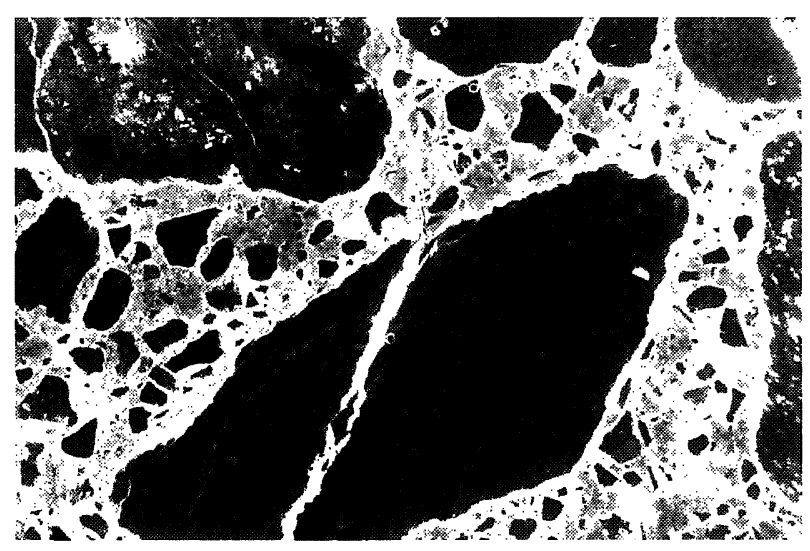

(a)

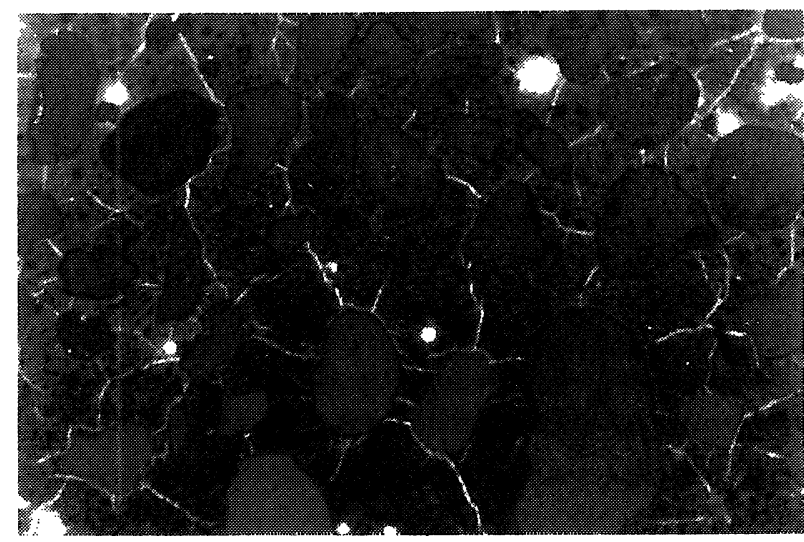

(b)

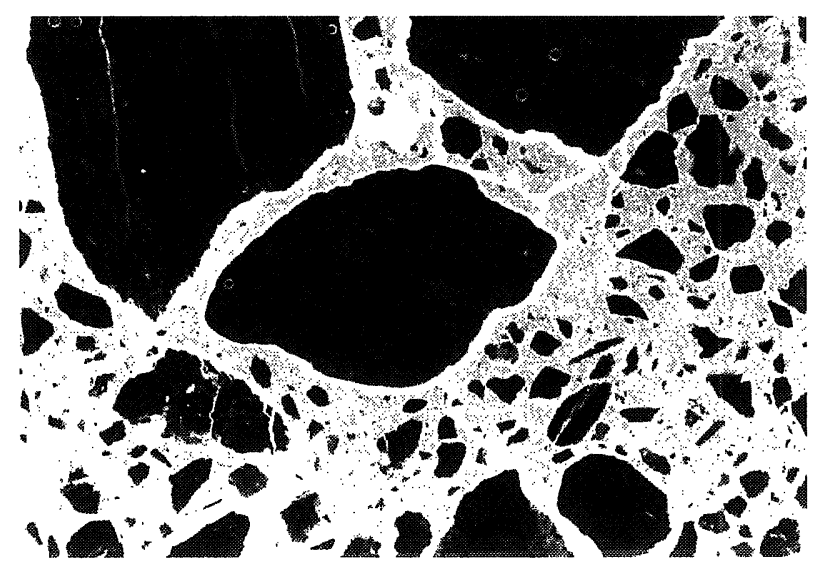

(c)

Fig. 7.- T"ipicos modelos de fisuración ocasionados por $\triangle$ SRR (a), retracción plástica (b). y hielo - deshielo (c)

Fïg. ?.- Typical crack patterns caused by ASR (a), plastic shrinkage (b), and freezing-thawing (c).

No es preciso decir que la preparación apropiada de las muestras es muy importante. Generalmente los mejores resultados se obtienen mediante el uso de una combinación de varias técnicas experimentales (microscopia óptica y microanalisis; microscopía de luz reflejada y de luz transmitida, etc).

\section{CONCLUSIONES}

El interés actual en torno al fenómeno DEF es el resultado de una serie de problemas de durabilidad, detectado en varios paises, y que se produce en elementos prefabricados de hormigón curados térmicamente. Algunos de estos casos han sido objeto de bien conocidos pleitos aunque, hasta el momento, pocos datos técnicos han sido sacados a la luz.

La controversia que rodea al fenómeno DEF está basada, a nuestro juicio, en una mala interpretación de los datos experimentales disponibles. De hecho, DEF es una de las muchas posibilidades del denominado ataque por sulfatos; posibilidad que se concreta en una expansión de la matriz de hormigón, debida a la
Veedless to say that proper sample preparation is important. Best results are obtained by using $a$ combination of several experimental techniques (optical and SEM / analysis; thin sections and polished sections; BSLE. EDS microanalysis; other analytical techniques).

\section{CONCLUDING REMARKS}

The present interest in DEF is the result of durability problems encountered with heat-cured. prefabricated concrete products in several countries. Some of these cases were subject to well publicized litigations but few technical data were released until recently.

The controversy surrounding the IDEF issue is based on misunderstanding and misinterpretation of available experimental data. In fact, IJEF is one of many representations of so-called sulfate attack and is specifically caused by expansion of the concrete matrix due to formation in the hardened paste of 
formación en la pastá endurecida de etringita retrasada microcristalina a causa de la descomposición térmica previa (exceso de calor, secado) de la etringita primaria formada en las primeras etapas de la hidratación del cemento. Tal descomposición libera en el sistema (fase acuosa de los poros, C-S-H, etc.) los iones necesarios para la formación de etringita; así, tras un enfriamiento y un almacenamiento en condiciones húmedas, la formación retrasada de una etringita, homogéneamente distribuida dentro de la pasta, se hace posible.

Durante la vida util del hormigón, especialmente en presencia de humedad, la etringita primaria y/o retrasada recristalizará lentamente en los espacios más grandes disponibles. La formación de tal etringita secundaria no es expansiva y puede observarse en la mayoria de los hormigones no dañados. En aquellos casos en los que el hormigón se ha físurado debido a otros mecanismos de deterioro, tales como ASR, hielodeshielo, o retracción, las fisuras pueden rellenarse de etringita secundaria.

El fenómeno de la DEF se caracteriza por la formación de brechas alrededor las partículas de árido. Tales brechas pueden, o no, rellenarse de etringita. La presencia de etringita secundaria en huecos, fisuras y otros espacios no es perse un indicio de DEF. Las pastas de cemento se sabe que expanden debido a la DEF en ausencia de tales espacios.

En lo que a la experiencia de los autores del presente trabajo respecta, no tienen justificación los argumentos que sostienen que los clínkeres de cemento con altos contenidos en azufres (aproximadamente por encima del 1,5 a $2,0 \%$ ) tienen anhidrita, y por tanto no disponen de sulfatos para las reacciones de hidratación en las primeras edades. En la mayoria de los clinkeres, el sulfato está presente en forma de sulfato alcalino o cálcico - alcalino, con una muy pequeña proporción de sulfatos incorporados en las fases del clínker,

fundamentalmente en los silicatos cálcicos.

Tampoco creemos que los sulfatos procedentes de los combustibles de desecho represente un problema serio, dado que en la mayoría de los casos el contenido de álcalis de los crudos es suficientemente alto como para permitir la formación de sulfatos alcalinos en vez de sulfato cálcico. Al igual que en el caso previamente descrito, no hay ninguna evidencia en la literatura que demuestre tal argumentación.

El fenómeno DEF puede impedirse, siempre y cuando se empleen prácticas adecuadas en la fabricación y ejecución del hormigón. Consideraciónes muy serias han de darse especialmente en lo que respecta a las condiciones de curado, aunque no se deben obviar la microcrystalline delayed ettringite. This formation is made possible by prior thermal decomposition (excessive heating, drying) of the primary ettringite formed in early stages of cement hydration. Such decomposition releases into the system (pore liquid, C'$S-H$, etc.) the reactants needed for ettringite formation; thus, after cooling and storage in humid conditions, delayed formation of homogeneously-distributed ettringite within the paste is made possible.

During concrete use, especially in the presence of adequate moisture, primary and/or delayed ettringite will slowly recrystallize into the largest available spaces. Formation of such secondary ettringite is nonexpansive and it can be observed in most undamaged concrete. In cases where concrete is cracked due to other mechanisms of deterioration, such as $A S R$, freezing-thawing, or shrinkage, such cracks may get filled with secondary ettringite.

DEF is characterized by the formation of gaps around the aggregate particles; such gaps may or may not be filled with ettringite. The presence in gaps, cracks and voids of secondary ettringite is not per se an indication of DEF. Cement paste are known to expand due to IDEF in absence of such cracks.

In our experience, the claims that high-sulfur portland cement clinkers (above approx. 1.5 to 2.0\%) contain calcium sulfate anhydrite, thus sulfate not available for early hydration reactions; are unwarranted: most important, they are undocumented. In most industrial clinkers. sulfate is present in the form of alkali or calcium-alkali sulfates, with a small amount being incorporated in the clinker minerals, primarily in the calcium silicates.

Similarly, we do not believe that sulfate originating from waste fuels represents a serious problem, as in the majority of cases the alkali content of the raw mix is high enough to allow formation of calcium alkali sulfates rather than calcium sulfate. As in the above case, no evidence has been presented in literature to substantiate these claims.

DEF can be prevented if and when proper concreting practices are employed. Serious consideration should be given primarily to proper concrete processing. especially curing conditions, but also to concrete 
composición del hormigón y las condiciones ambientales en las que habrá de ser usado.

La detección de la DEF no sólo es posible, sino que las técnicas hoy dia disponibles permiten fácilmente distinguir entre dicho fenómeno y otras formas de deterioro, como por ejemplo la reacción árido-álcali (ASR), el hielo-deshielo, el ataque químico, el ataque externo de sulfatos, la retracción, etc. En la identificación de las causas que ocasionan los daños, no se debería confiar exclusivamente en los modelos de fisuración externa.

Finalmente, no es preciso decir que hay todavía muchas cuestiones por resolver con respecto al fenómeno DEF. Fundamentalmente aquéllas relacionadas con la necesidad de una mejor comprensión del mecanismo de expansión de la pasta. Una vez resueltas, los resultados tendrán que traducirse en metodologías de prevención y en la puesta a punto de métodos de ensayo específicos, precisos y fiables para determinar el fenómeno DEF.

\section{AGRADECIMIENTOS}

Los autores deseamos poner de manifiesto que, además de nuestros propios datos, la presente revisión se basa también en resultados de U.Ludwig, S. Diamond, D.C. Lawrence, H.F.W. Taylor, y, naturalmente, de sus colaboradores.

A Ulla Hjorth Jakobsen le agradecemos su trabajo con la microscopía y a los siguientes colegas su buena disposición para la discusión en torno al tema y por otras interesantes aportaciones: C. Andrade, R.D. Gaynor, J. Gebauer, G.M. Idorn; B. Mather, M.T. Blanco y $\mathrm{T}$. Vázquez. composition and to the environmental conditions it will be used in.

Detection of DEF is possible and there are techniques to easily distinguish between DEF and other forms of deterioration, e.g. ASR, freezing-thawing, chemical attack, external sulfate attack, plastic shrinkage, etc. In forensic identification of the causes of damage, one should not rely on external cracking pattern alone.

Needless to say, there are still some open question regarding $D E F$. These are primarily related to need for better understanding of the mechanism of paste expansion. Once solved, the results will have to be translated into prevention methodologies and specific, acurate, and reliable DEF test methods.

\section{ACKNOWLEDGMENTS}

We would like to acknowledge that, in addition to our own data, the presented review is based primarily on results of U.Ludwig, S. Diamond, D.C. Lawrence, H.F.W. Taylor, and their coworkers.

Ulla Hjorth Jakobsen is acknowledged for her microscopic work. We would also like to thank the following colleagues for discussions and other input: C. Andrade, R.D. Gaynor, J. Gebauer, G.M. Idorn, B. Mather, M.T. Blanco and T. Vázquez.

\section{BIBLIOGRAFÍA}

(1) R.C.MIELENZ, S.L.MARUSIN, W.G.HIME, AND Z.T.JUGOVIC: "Investigation of Prestressed Concrete Railway Tie Distress", Concrete International, ACI, December 1995, 62-68.

(2) S.L.MARUSIN: "SEM Studies on DEF in Hardened Concrete", Proc.15th Int.Conf.Cement Microscopy (G.Gouda,A.Nisperos,J.Bayles, Eds.), ICMA, 1993, 289-299; see also: "Deterioration of Railroad Ties in the USA", in Proc. CANMET/ACI Int. Workshop on AAR in Concrete, Nova Scotia, 1995, 243-256.

(3) (a) V.JOHANSEN, N.THAULOW, AND J.SKALNY: "Simultaneous Presence of Alkali-Silica Gel and Ettringite in Concrete", Adv.Cem.Res., 5(1993), 23-29; (b) unpublished data from evaluation of industrial concrete products.

(4) V.JOHANSEN, N.THAULOW, U.H.JACOBSEN, AND L.PALBOL: "Heat-curing Induced Expansion", 3rd Beijing Int.Symp. on Cement and Concrete, Beijing, 1993; see also: Johansen et al, "Expansion Reactions in Mortar and Concrete", Zement-KalkGips 3(1994),150-155 and N.Thaulow et al. "What Causes Delayed Ettringite Formation?", presentation at the 1995 MRS symposium, Boston, MA, December 1995. 
(5) V.JOHANSEN, N.THAULOW, AND J.SKALNY: “Chemical Degradation of Concrete", presentation at the 1995 TRB meeting, Washington, D.C., January 1995; see also: "Internal Reactions Causing Cracking of Concrete", Beton + Fertigteil Technik 11(1995),56-68.

(6) H.F.W.TAYLOR: "Delayed Ettringite Formation", in Advances in Cement and Concrete (M.W.Grutzek \& S.L.Sarkar, Eds.), American Society of Civil Engineers, 1994; see also: "Sulfate Reactions - Microstructural and Chemical Aspects", in Cement Technology, Ceramic Transactions 40(194), 61-78.

(7) K.L.SCRIVENER AND H.F.W.TAYLOR: "Delayed Ettringite Formation: A Microstructural and Microanalytic Study", Adv.Cem.Res.5(1993), 139-146.

(8) C.D.LAWRENCE: “Delayed Ettringite Formation: An Issue?", in Materials Science of Concrete IV(J.Skalny \& S.Mindess, Eds.), The American Ceramic Society, Westerville, OH, 1995, 113-154.

(9) S.DIAMOND AND ONG: "Combined Effect of Alkali Silica Reaction and Secondary Ettringite Deposition in Steam Cured Mortars", in Ceramic Trans. 40(1994), 79-90; see also: S.Diamond, Ong, and D.Bonen, "Characteristics of Secondary Ettringite Deposited in Steam Cured Concrete Undergoing ASR", in Proc. 16th Int.Conf.Cement.Microscopy, 1994.

(10) N.THAULOW ANDU.H.JACOBSEN: “The Diagnosis of Chemical Deterioration of Concrete by Optical Microscopy", presented at the 1995 MRS Symposium, Boton, MA, December 1995.

(11) P.K.MEHTA: "Sulfate Attack in Concrete-A Critical Review", in Materials Science of Concrete III (J.Skalny, Ed.), The American Ceramic Society, Westerville, OH, 1992, 105-130.

(12) TEPPONEN, P. AND ERIKSON, B.E.: "Damages in Concrete Railway Sleepers in Finland", Nordic Concrete Research, Nr 6, 199-209 (1987).

(13) AIF-RESEARCH PROJECT NR 4873: "Influence of Heat Treatment on the Chemical Reactions in Cement" (in German), Research Institute of the Cement Industry, Tannenstrasse 2, 4000, Dusseldorf 30, Germany.

(14) SYLLA, M.-H: “Reactions in Cement Paste Due to Heat Curing” (in German), Beton 38 [11], 449-454, 1988; see also: W.Wieker and R.Herr, "On Some Problems of the Chemistry of Portland Cement", Zeitsch. fur Chem.29(1989),321-327.

(15) NECK, U.: "Effects of Heat Curing on Strength and Durability of Concrete" (in German), Beton 38 [12], 488-493, 1988.

(16) HEINZ, D.: "Schadigende bildung Ettringit- ahnlicher Phasen in Warmebehandelten Morteln und Betonen", Thesis, ReinischWestfalichen Technischen Hochschule Aachen, 1986; also: Heinz, D., Ludwig, U., "Mechanism of Subsequent Ettringite Formation in Mortars and Concrete after Heat Treatment". Proc. 8th Int. Congr. on the Chemistry of Cement, Rio de Janeiro, 1986, Vol. V, 189-199; Heinz, D., Ludwig, U.,"Mechanism of Secondary Ettringite Formation in Mortars and Concretes Subjected to Heat Treatment". Ed. J.M.Scanlon, ACI, Detroit, SP 100-105. Katharine and Bryant Mather International Conference; and other papers.

(17) LAWRENCE, C.D., DALZIEL, J.A., HOBBS, D.W.,: "Sulphate Attack Arising from Delayed Ettringite Formation." Interim Technical Note No. 12, 43 pp, British Cement Association, 1990.

(18) I. ODLER ANDI. JAWED: “Expansive Reactions in Concrete”, in Materials Science of Concrete III(J.Skalny \& S.Mindess, Eds.), The American Ceramic Society, Westerville, OH, 1991, 221-247.

(19) B.MATHER: discussion of paper "Effects of Urea on Durability of Reinforced Concrete", Mag. Concr. Res. 47 (1995), 93-94.

(20) S. DIAMOND: “Combined Alkali Silica Reaction - Secondary Ettringite Problems: A Current Assessment”, Concrete Across Borders, Odense, June 1994, 191-203.

(21) H. INSLEY: "Petrographic Examination of Specimens in Series 173", Letter to R.D.Gaynor, 16 September 1966.

(22) F.E. JONES: “The Quarternary System CaO- $\mathrm{Al}_{2} \mathrm{O}_{3}-\mathrm{CaSO}_{4}-\mathrm{H}_{2} \mathrm{O}$ at $25^{\circ} \mathrm{C}$ ” Trans.Faraday Soc.35 (1939), 1434-1510; also: J. Phys. Chem. 44 (1944),311-356; ibid, 356-378; ibid, 379-394.

(23) A.S. BERGER: “On Metastable Equilibrium of Calcium Hydroaluminates in Solution of Hydroxides of Alkali Metals", in Proc. 6th Int. Symp. Cem. Chem., 1974, Vol.III, 1-12, Moscow.

(24) I. ODLER: "Interaction Between Gypsum and the C-S-H Phase Formed in C 3 S Hydration", 7th Int.Congr.Chem. Cem., Paris (1980), Vol.IV, 493-495; see also: "Effect of Hydration Temperature on Cement Paste Structure", Proc. MRS Symp.85(1987), 139-144 
(25) W. LIEBER,: "Ettringite Formation at High Temperature", Zement Kalk Gips 9(1963),364-365.

(20) P.W. BROWN AND J.V. BOTHE: "The Stability of Etringite", Adv. Cem. Res. 5(1993),47-63; see also: E. Grusczscinski et al., Cem. Concr. Res. 23(1993),981-987.

(27) P.K. MEHTA,: "Stability of Ettringite on Heating”, J. Am. Ceram. Soc.(1972), 55-56.

(28) D. DAMIDOT AND F.P. GLASSER: "Thermodynamic Investigation of the $\mathrm{CaO}-\mathrm{Al}_{2} \mathrm{O}_{3}-\mathrm{CaSO}_{4}-\mathrm{H}_{2} \mathrm{O}$ System at $25^{\circ} \mathrm{C}$ and the Influence of $\mathrm{Na}_{2} \mathrm{O}$ ", Cem. Concr. Res. 23 (1993), 221-238; also: "Thermodynamic Investigationof the CaO- $\mathrm{Al}_{2} \mathrm{O}_{3}-\mathrm{CaSO}_{4}-\mathrm{H}_{2} \mathrm{O}$ System at $50^{\circ} \mathrm{C}$ and $85^{\circ} \mathrm{C} "$, ibid, 22(1992), 1179-1191.

(29) M.C. LEWIS And K.L. SCRIVENER: "Microchemical Effects of Elevated Temperature Curing and Delayed Ettringite Formation", 1996, in preparation; see also: M.C .Lewis et al.,"Heat Curing and Delayed Ettringite Formation", MRS Symp. Proc.370(1995),67-76.

(30) YAN FU et al., "A Kinetic Study of Delayed Ettringite Formation in Hydrated Portland Cement Paste", Cem. Concr. Res. 25 (1995), 63-70.

(31) W.G. HIME: presentation at PCA, Skokie, IL, June 1995; also: R.L.Carrasquillo, presentation at the University of Texas, Austin, TX, 8 February 1996.

(32) D. HEINZ: PhD Thesis, RWTH Aachen, 1986.

(33) E. GRABOWSKI: B.Czarneczki, J.E.Gillott, C.R.Duggan, and J.F.Scott, "Rapid Test of Concrete Expansivity Due to Internal Sulfate Attack", ACI Matls. J., 1992, 469.

(34) H.-J. KUZEL: "Reaction of $\mathrm{CO}_{2}$ with Calcium Aluminate Hydrates in Heat Treated Concrete", Proc. 12th Int. Conf. Cement Microscopy, 1990, 218-227.

(35) K.L. SCRIVENER: "The Microstructure of Concrete", in Materials Science of Concrete I(J.Skalny, Ed.), The American Ceramic Society, 1989, 127-161; see also: "The Effect of Heat Treatment on Inner Product C-S-H". Cem.Concr.Res.22(1992),6, 12241226

(36) B.A. CLARK, E.A. DRAPER, R.J. LEE, J. SKALNY, A. BEN-BASSAT, And A. BENTUR: "Electron-optical Evaluation of Concrete Cured at Elevated Temperatures", in Durable Concrete in Hot Climates, ACI SP-139, 1993, 41-59; see also: Y.Jie et al.,'Temperature Relics in Steam Cured Concrete", Proc. Int. Cem. Microsc. Assoc. 1993,289-299; also: E.A.Draper et al., “Alugnos Aspectos Microstructurales del Deterioro del Hormigon", Mater.de Construction 43(1993), 5-19.

(37) P. GOLTERMAN and J. HOLM: "Fracture Mechanical Considerations in the Assessment of Deteriorating Mechanisms in Concrete”, Proc. ACI Int. Conf. Eval. Rehab. Concrete, Hong Kong, 1991, 323-338.

(38) I. DE LACRUZ, T. VÁZQUEZ and O. FERNÁNDEZ-PEÑA: "IR spectroscopy of sulphates in clinkers and cements". Materiales de Construcción. Vol. 36, $\mathrm{n}^{\circ} 201,1986,25-42$. 


\title{
Publicaciones del Instituto Eduardo Torroja - CSIC
}

\author{
Números monográficos de INFORMES
}

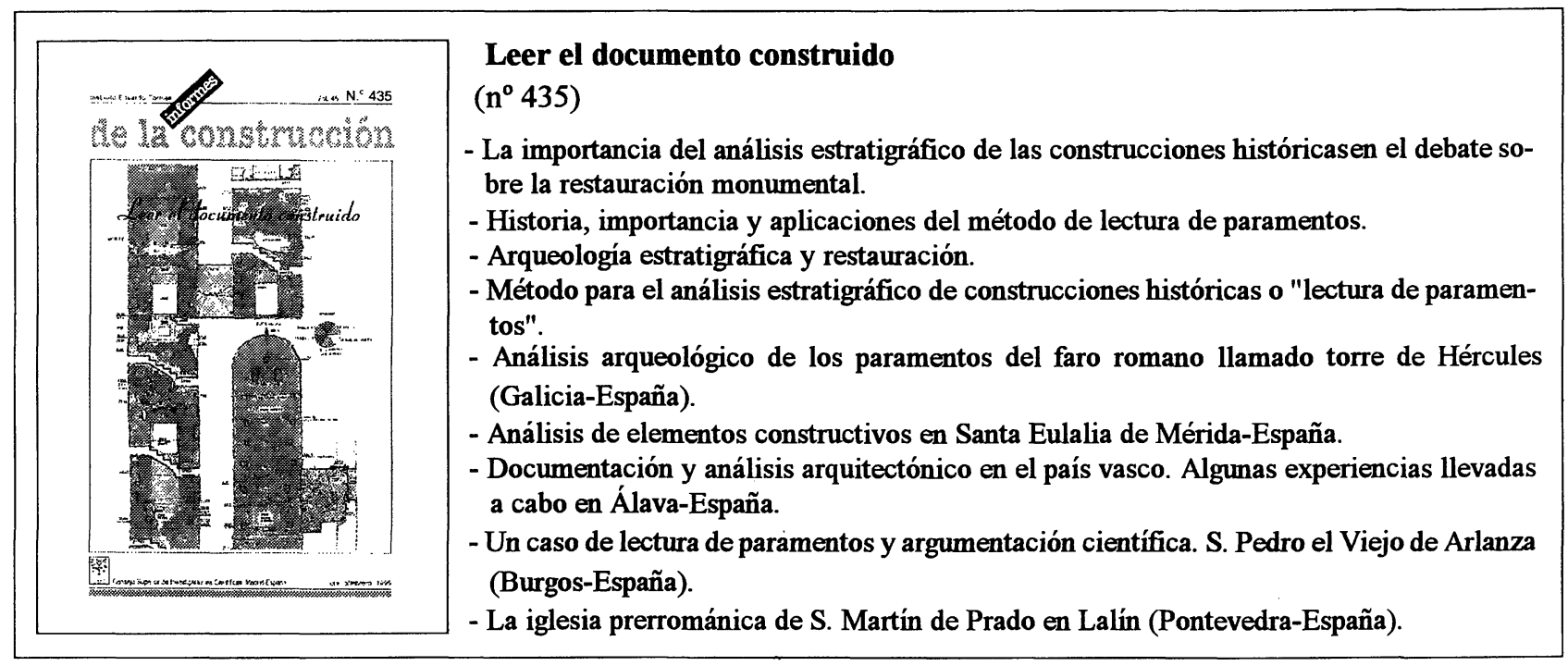

\begin{tabular}{|c|c|}
\hline 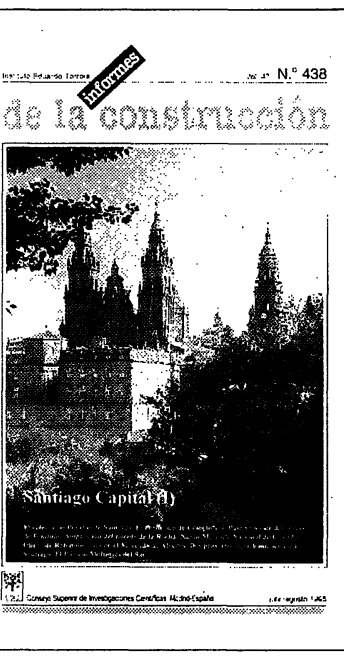 & $\begin{array}{l}\text { Santiago Capital } \\
\left(n^{\circ} 438\right) \\
\text { - El color a las puertas de Santiago. } \\
\text { - Un nuevo camino en Santiago, el periférico de Compostela. } \\
\text { - Paso superior del enlace de Fontiñas en la nueva red periférica de Santiago de Compostela. } \\
\text { Retorno a Stonehenge. } \\
\text { - El puente de La Rocha en Santiago de Compostela: Ampliación de dos a cuatro carriles de } \\
\text { circulación del puente existente en el KM } 67 \text { de la CN-550 de La Coruña a Santiago y Tuy. } \\
\text { - Nuevo mercado nacional de Ganado. } \\
\text { - Obras de rehabilitación en el mercado de abastos de la ciudad histórica de Santiago de } \\
\text { Compostela. } \\
\text { - Dos proyectos de urbanización en Santiago. } \\
\text { - Palacio multiusos del Sar. }\end{array}$ \\
\hline
\end{tabular}

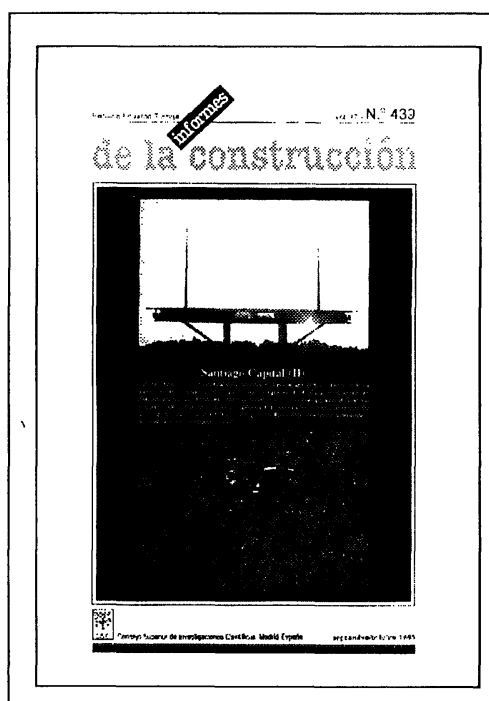

$\left(n^{\circ} 439\right)$

- La transformación urbanística de Compostela. El planeamiento urbano al servicio de un proyecto de desarrollo (Galicia-España).

- Palacio de Congresos y Exposiciones de Galicia en Santiago (Galicia-España).

- Nueva instalación de Telecomunicaciones. Santiago de Compostela (Galicia-España).

- Centro de Arte Contemporáneo de Galicia en Santiago de Compostela (Galicia-España).

- Escuela Pública "Carme de Abaixo". Santiago de Compostela (Galicia-España).

- Avenida Xoan XXIII. Santiago de Compostela (Galicia-España).

- Edificios para Instituto de Investigación de la Universidad de Santiago. Santiago de Compostela (Galicia-España).

- La Oficina Municipal de Conservación y Rehabilitación de la Ciudad Histórica de Santiago de Compostela (Galicia-España). 